\title{
Average leaf litter quality drives the decomposition of single-species, mixed-species and transplanted leaf litters for two contrasting tropical forest types in the Congo Basin (DRC)
}

\author{
Benoît Cassart $^{1,2} \cdot$ Albert Angbonga Basia $^{3} \cdot$ Mathieu Jonard $^{1} \cdot$ Quentin Ponette $^{1}$ \\ Received: 17 April 2019 / Accepted: 12 March 2020 / Published online: 26 March 2020 \\ (C) INRAE and Springer-Verlag France SAS, part of Springer Nature 2020
}

\begin{abstract}
- Key message Under similar site conditions, leaf litter decomposition beneath Central African rainforests was largely driven by average leaf litter quality. Although significant, the additional variability related to litter mixing and to the decomposition environment was limited.

- Context Under given site conditions, litter decomposition is expected to mainly depend on its average quality. However, the additional impacts of litter diversity as well as of the local decomposition environment remain rather inconclusive.

- Aims This study investigates the litter mixture effects on decomposition and home-field advantage for two emblematic old growth forest types of the Congo Basin: the Scorodophloeus zenkeri Harms mixed forests and the evergreen Gilbertiodendron dewevrei (De Wild.) J. Léonard monodominant forests.

- Methods Based on a litterbag experiment, variations in leaf litter mass loss were measured from the eight most important tree species under mixed and monodominant forests and for all possible two-species combinations.

- Results Remaining mass was largely explained (90\%) by a multivariate measure of initial litter quality including 11 functional traits, which performed better than any single leaf litter trait. For the litter mixtures, the average deviation from expectation based on simple additive effects ranged from slightly synergistic $(+2.56 \%)$ to slightly antagonistic $(-0.86 \%)$ after 1 and 6 months, respectively. Mixture identity and chemical dissimilarity contributed to explaining the mixing effects, yet the effect of chemical dissimilarity at the whole mixture level was only detected through an interaction with incubation time. In addition, the initial decomposition rates of $S$. zenkeri and G. dewevrei were accelerated under their own forest type.

- Conclusion In agreement with the "home-field advantage" theory, our results highlighted that the functional composition of the host forest did have an indirect impact on decomposition. In addition, leaf litter decomposition was mainly controlled by average litter quality, which in turn was closely related to a multivariate measure of green leaf quality. This suggests that increased knowledge of tree species leaf traits in tropical forests would greatly help in better understanding the litter decomposition dynamics.
\end{abstract}

Keywords Litter chemistry · Gilbertiodendron dewevrei $\cdot$ Scorodophloeus zenkeri $\cdot$ Litter mixture $\cdot$ Home-field advantage · Species identity effects

Handling Editor: Ana Rincon

Benoît Cassart

cassartb@gmail.com

Albert Angbonga Basia

albert_angbonga@yahoo.fr

Mathieu Jonard

Mathieu.jonard@uclouvain.be

Quentin Ponette

quentin.ponette@uclouvain.be
1 UCLouvain-ELI, Earth and Life Institute, Université catholique de Louvain, Croix du Sud 2, L7.05.09, 1348 Louvain-la-Neuve, Belgium

2 ERAIFT, Ecole Régionale Post-universitaire d'Aménagement et de Gestion Intégrés des Forêts et Territoires Tropicaux, Kinshasa, Democratic Republic of the Congo

3 Institut Facultaire des Sciences Agronomiques de Yangambi, Yangambi/Kisangani, Democratic Republic of the Congo 


\section{Introduction}

In terrestrial ecosystems, most of the plant net primary production ends to the soil as litter (Cebrian 1999). Through its impact on carbon, nutrient and water cycles, litter decomposition is a central ecosystem process, at both global and local scales (Chapin et al. 2011). Litter decomposition is determined by multiple key drivers including climate, litter quality, sitespecific factors (such as soil properties) and the decomposer community (Coûteaux et al. 1995; Aerts 1997; Hättenschwiler et al. 2005). Under similar conditions of macroclimate, topography and soil, the decomposition of litter is expected to first depend on its average quality, through the provision of resources, habitat and secondary, possibly inhibitory, compounds to the decomposers and detritivores. However, the diversity of litter (Gartner and Cardon 2004; Hättenschwiler et al. 2005; Oliveira et al. 2019) and the local decomposition environment (Jewell et al. 2015; Joly et al. 2017) both have been shown to further impact the decomposition process, yet their relative contribution remains poorly documented. Most studies addressing the drivers behind the variability in litter decomposition under tropical rainforests have been carried out in the Amazon Basin (Hättenschwiler et al. 2011; Nottingham et al. 2018; Oliveira et al. 2019; Four et al. 2019). Several decomposition studies have been conducted in Central Africa (Bernhard-Reversat and Schwartz 1997; Torti et al. 2001; Chuyong et al. 2002; Peh 2009; Peh et al. 2012), yet we still have a limited understanding of the decomposition process and its drivers for major African rainforest types, especially in the Democratic Republic of the Congo.

In mixed-species plant communities, the decomposition of leaf litter mixtures may exhibit additive and non-additive effects. Non-additive effect occurs when the decomposition rate of a litter species in the mixture departs from expectations based on single-species litters. This is in contrast to Grime's biomass ratio hypothesis that states litter decomposition is driven by community-weighted mean (CWM) traits (Grime 1998), which precludes any non-additive effects.

Interactive effects have been attributed to a number of direct or indirect processes (e.g. see Hättenschwiler et al. (2005) and Gessner et al. (2010) for a review). Different tree species influence decomposition rate directly through species-specific litter characteristics and indirectly through changes in understorey environment conditions and in decomposer community (Wardle 2006; Scherer-Lorenzen 2008). In a given environment, the magnitude and direction of those interactions may differ strongly, from synergistic to antagonistic or no effects at all, depending chiefly on the species composition, and more precisely, on the variation of litter traits in the mixture (e.g. Lecerf et al. 2011). In particular, when chemically contrasted leaf litters are present, limiting resources in one target litter could be compensated for by active microbial transfer of nutrients or passive transfers through leaching from accompanying litter (Gessner et al. 2010). Based on such mechanisms, the difference in nutrient composition between constituting leaf litters, further referred to as chemical dissimilarity, is expected to 'boost' interactive leaf mixing effects (Hoorens et al. 2003, 2010). On the other hand, inhibitory compounds leached from some leaf species could induce negative effects (Hättenschwiler et al. 2005). Through a toxic effect on soil biota, both tannins and lignin (Scalbert 1991; Schimel et al. 1996) may inhibit microbial enzyme activity (Joanisse et al. 2007) or complex proteins (Kraus et al. 2003) resulting in a reduction of decomposition rate.

In addition to these direct litter mixture-driven diversity effects, indirect biotic and abiotic control associated with plant community composition can also modify the decomposition process as was shown by Joly et al. (2017) across European forests. In their case, the biotic control was mostly affected by the local litter, which interacted with their standard substrates (cellulose and wood). This result suggests that the locally produced leaf litter acts beyond immediate direct quality effects, by shaping the local decomposer community through long-term selective pressure (Ayres et al. 2009; Freschet et al. 2012a).

This latter interpretation is in line with the home-field advantage (HFA), where litter decomposes faster in its own plant environment than away, an effect that has been explained by the specialisation of local decomposer communities due to selective pressure and evolutionary trade-offs in evolving specific enzymatic capacities (Ayres et al. 2009).

This HFA, however, appears to be context dependent, and the mechanisms at play are still under debate (Freschet et al. 2012a; Veen et al. 2018). Change in quality of input and matrix litters could affect patterns of HFA in many different ways (Veen et al. 2018). First, HFA could become stronger with decreasing quality of the input litter, as breakdown of that litter would require more specialised organisms in contrast to highquality litters (Wallenstein et al. 2013). Second, higher-quality litter environments could lead to increased competition between decomposers, resulting in increased specialisation and stronger HFA in those contexts (Fanin et al. 2014). Third, the functional breadth of decomposer communities (i.e. the range of organic compounds such communities are able to process) could be higher in low-quality litter matrix, allowing decomposer communities from low litter quality environments to decompose a wide range of litter types (van der Heijden et al. 2008). Fourth, each litter type could have its own specialised decomposer community, and the extent of HFA would therefore depend on the dissimilarity between that litter and the average litter matrix the decomposers are supposed to be adapted to (substrate quality-matrix quality interaction, SMI hypothesis; Freschet et al. 2012a). The SMI hypothesis assumes that the decomposition of any specific litter depends on the (dis-)similarity between its own quality and the average value of the matrix litter (Freschet et al. 2012a). Under SMI, low-quality litters are predicted to decompose faster than 
expected in a decomposition-matrix of poor quality and slower than expectation in high-quality litter environments. Finally, besides the average litter quality of the litter matrix, the functional diversity of that matrix could allow the coexistence of a wider range of decomposer communities; for HFA to hold under such situations, a positive interaction for all different litter types at their own site should be assumed, which is however highly unlikely.

Due to the major contribution of tropical forests to the global carbon cycle, a better understanding of the decomposition process under such forests is critically important.

In this paper, we focus on the direct litter mixture-driven diversity effects as well as on HFA and assess their contribution to the overall decomposition process compared to that of average litter quality for two emblematic old growth forest types of the Central Congo Basin: the Scorodophloeus zenkeri Harms mixed forests and the evergreen Gilbertiodendron dewevrei (De Wild.) J. Léonard monodominant forests, hereafter called mixed forests and monodominant forests, respectively. These two forest types cover extensive areas in the zone, where they frequently co-occur on similar ecological conditions on a wide variety of soils (Hart et al. 1989; Kearsley et al. 2017). Gilbertiodendron dewevrei is a tree species that commonly forms monodominant forests (Connell and Lowman 1989), that is forests where one single tree species dominates in the upper canopy layer. The dominance of Gilbertiodendron dewevrei was previously shown to be tightly linked with a set of litter traits inhibiting decomposition leading to a limited development/growth of other tree species (Peh et al. 2011). In addition, Cassart et al. (2017) demonstrated that strong soil organic carbon (forest floor and mineral soil) accumulation under monodominant forests was related to these traits. By contrast, mixed forests are characterised by the coexistence of a large species pool (Torti et al. 2001; Djomo et al. 2011), which results in litter spanning a wide range of traits (Cassart et al. 2017).

Building on the wide range of leaf litters traits associated with the large pool of tree species, we first investigated the impact of leaf litter quality on decomposition for single and mixed-species litterbags, using a multivariate measure of litter quality. We then compared observed and expected decomposition for two-species leaf litter mixtures at the whole mixture and at the component species level and quantified the mixture effect by means of a multivariate measure of trait dissimilarity between the component species. Finally, we compared the decomposition of the dominant species, Gilbertiodendron dewevrei and Scorodophloeus zenkeri, in both forest types to investigate the HFA.

We hypothesised that:

i. Compared to average leaf litter quality, the contributions of chemical dissimilarity in litter mixture induced by functional diversity as well as of HFA to the overall decomposition process are limited. ii. Synergistic litter mixture effects on decomposition increase with chemical dissimilarity of leaf litter mixtures.

iii. In agreement with the HFA hypothesis, S. zenkeri and $G$. dewevrei litter decomposition are favoured under mixed and monodominant forests, respectively.

\section{Materials and methods}

\subsection{Study site}

This study was conducted in the Yoko Forest Reserve in the Tshopo Province of the Democratic Republic of Congo (Fig. 1). The Reserve is located on a sandy plateau at about $28 \mathrm{~km}$ south of Kisangani (N 00 19' 12"; E $2517^{\prime}$ 43") and $450 \mathrm{~m}$ of elevation and covers an area of 6975 ha.

According to the revised Köppen-Geiger classification, the regional climate is described as Af-type tropical rainforest climate (Peel et al. 2007). Based on the meteorological data collected from the Yangambi station (located $100 \mathrm{~km}$ to the west of Kisangani) between 1961 and 2009, mean annual rainfall is $1780( \pm 230) \mathrm{mm}$ with two distinct rainy seasons (March-June and August-December), and a cumulated dry season length of ca 3 months (January-February and July) with monthly precipitation lower than $60 \mathrm{~mm}$ (Fig. 1). The mean annual air temperature is $24.8^{\circ} \mathrm{C}$ with limited seasonal variability. The dominant soil type is classified as Xanthic Ferralsol (Van Ranst et al. 2010) mostly composed of quartz sand, with low content of kaolinite clay and hydrated iron oxides.

The vegetation of the reserve is dominated by pristine moist semi-deciduous rainforest mixed with variable patches of moist evergreen rainforests. Few transition forests and slash-and-burn agriculture areas are found on the west side of the reserve, along the main road from Yoko to Biaro.

A preliminary survey allowed us to select areas of the Reserve dominated either by semi-deciduous Scorodophloeus zenkeri Harms mixed forests or by evergreen Gilbertiodendron dewevrei (De Wild.) J. Léonard monodominant forests, in otherwise similar topographic and edaphic conditions. While the stand basal area, stand density and soil characteristics were comparable between both forest types, species composition and diversity strongly differed (Cassart et al. 2017). Both mixed and monodominant forests are on nutrient poor $(\mathrm{CEC} \leq$ $\left.5.3 \mathrm{cmol}_{\mathrm{c}} \mathrm{kg}^{-1}\right)$ and strongly acidic soil $(\mathrm{pH} \leq 4.2)$ with high total sand (coarse + fine) content $(>86 \%)$ in the topsoil.

\subsection{Tree species selection and collection of leaves}

Eight tree species were involved in the experiment: Anonidium mannii (Oliv.) Engl. \& Diels, Cynometra hankei Harms, Gilbertiodendron dewevrei (De Wild.) J. Léonard, Guarea thompsonii Sprague \& Hutch, Julbernardia seretii 
a)

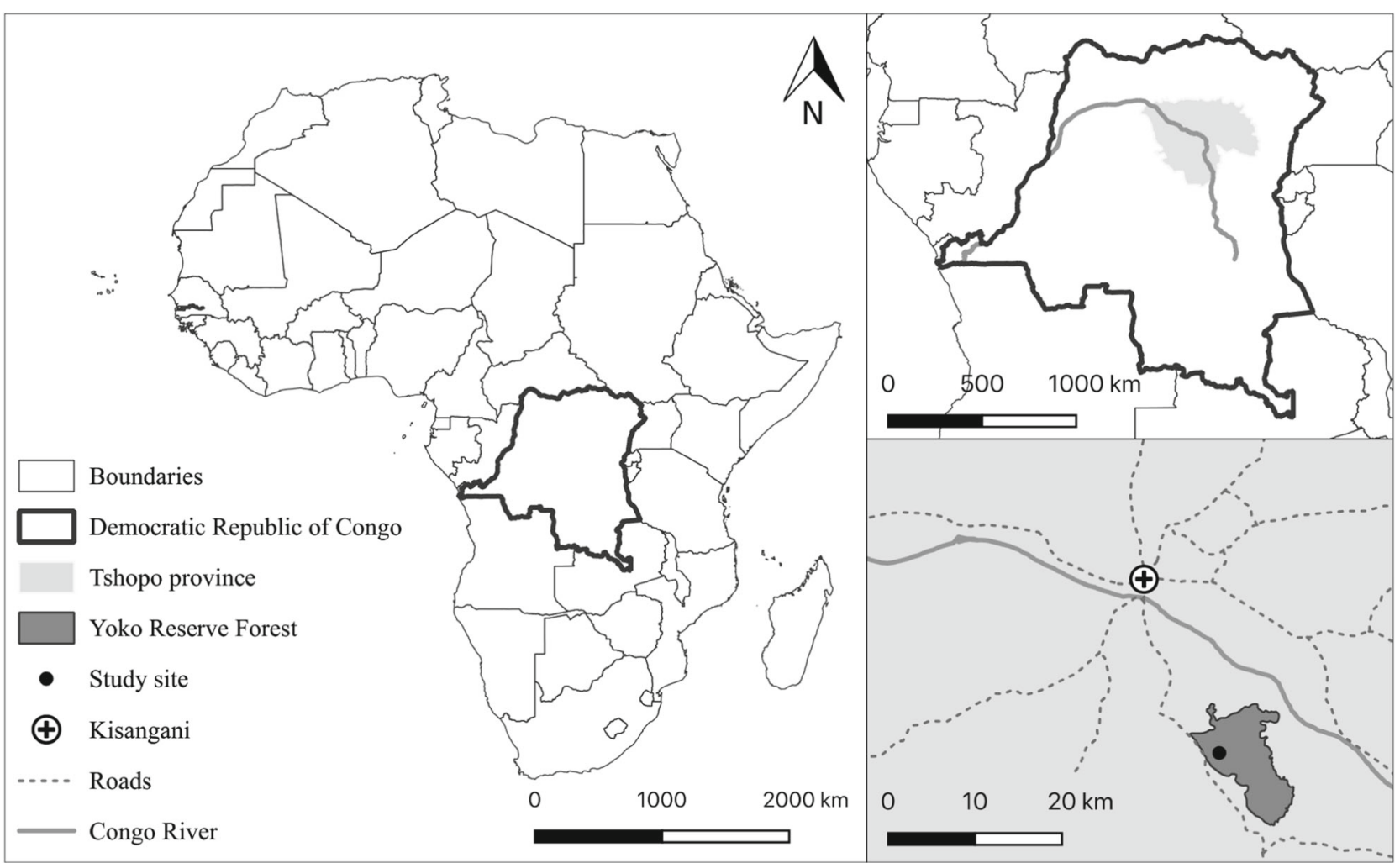

b)

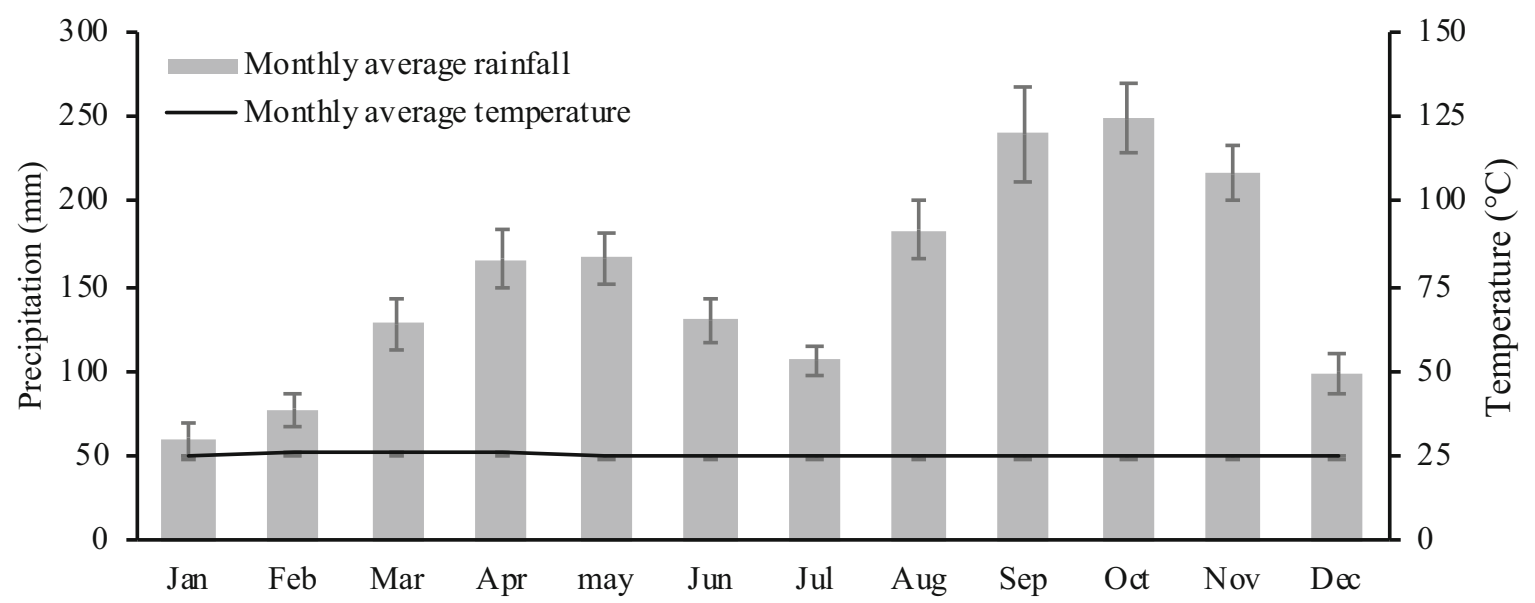

Fig. 1 a Map of the study location at Yoko Forest Reserve in the Tshopo Province of the Democratic Republic of Congo. b Ombrothermic diagram recorded during 2000-2014 in the meteorological station of Yangambi (located $100 \mathrm{~km}$ to the west of our site)

(De Wild.) Troupin, Polyalthia suaveolens Engl. \& Diels, Prioria oxyphylla (Harms) Breteler and Scorodophloeus zenkeri Harms; with the exception of $G$. dewevrei, all those species are found in both forest types. These tree species accounted for 48.7 and $84.6 \%$ of total basal area in mixed and monodominant forests, respectively. They were chosen to maximise the range of leaf functional traits, especially $\mathrm{CN}$ ratio and were therefore supposed to decompose at different rates.

Newly senescent leaf litter of these tree species was collected in 20 litter traps randomly placed in mixed and monodominant forests during the peak litter fall (February 2014) and were pooled and homogenised per tree species; if necessary, newly senesced leaves were collected from the forest floor. Fresh green leaves were collected from the sunexposed part of the crown of these eight tree species. Relatively young but fully expanded and hardened leaves were chosen, if possible undamaged without pathogen. A minimum of 10 individuals per species were selected throughout the corresponding tree species diameter distribution obtained from the dendrometric inventory (see Cassart et al. 2017). Subsample of green leaves was taken to estimate specific leaf area (SLA). The remaining part of green leaves samples and leaf litter material was directly air-dried and further oven-dried at $40{ }^{\circ} \mathrm{C}$ in the lab and stored in sealed plastic bags 
until further use. Subsamples of litter from each tree species were oven-dried at $65^{\circ} \mathrm{C}$ during $48 \mathrm{~h}$ to determine their water content and convert fresh litter mass into dry litter mass.

\subsection{Characterisation of the leaves}

We estimated specific leaf area (SLA - one-sided area of a fresh leaf, divided by its oven-dry mass) by first scanning a subsample of green leaves of each target tree species to determine the fresh leaf area using the ImageJ software, and then drying at $65^{\circ} \mathrm{C}$ and weighing to determine the corresponding leaf dry mass.

Composite subsamples of green and newly senescent leaf litter from each tree species were air-dried, ground and stored (at room temperature away from light and humidity) for chemical analyses. $\mathrm{C}$ and $\mathrm{N}$ concentrations of each sample were measured with a Flash EA CN 1112 series elemental analyser (Thermo Fisher Scientific, MA, USA). Calcium (Ca), potassium $(\mathrm{K})$, magnesium $(\mathrm{Mg})$, manganese $(\mathrm{Mn})$, phosphorus $(\mathrm{P})$, sulphur $(\mathrm{S})$ and silicon $(\mathrm{Si})$ concentrations were determined by inductively coupled plasma spectrometry following total acid digestion (a mixed solution of nitric and hydrofluoric acids) in a Milestone UltraWAVE microwave digestion system. Lignin and cellulose contents were determined only on leaf litter based on the method proposed by Van Soest and Wine (1967), using a Gerhardt (Königswinter, Germany) FibreBag apparatus.

\subsection{Litter decomposition experiment}

Litterbags $(15 \times 15 \mathrm{~cm})$ were made from plastic insect screen with ca. $2 \mathrm{~mm}$ mesh size. This mesh size avoids litter fragment losses and prevents all macrofauna (e.g. macroarthropods, isopods and earthworms) from entering while still allowing access to mesofauna such as mites, springtails and termites (Swift et al. 1979). Each litterbag received a total mass of $13 \mathrm{~g}$ dry litter, equivalent to $580 \mathrm{~g} \mathrm{~m}^{-2}$, which is consistent with annual aboveground litterfall input in mixed and monodominant forests (Cassart et al. 2017). To preserve the leaf structural properties, leaves were not ground or cut, except $G$. dewevrei, which was cut into $15 \mathrm{~cm}$ lengths to fit into the litterbags.

In order to investigate individual leaf litter decay rate, we incubated single-species litter of each studied tree species $(n=$ 8 ) under mixed forests. Litterbags were incubated in 5 blocks approximatively $100 \mathrm{~m}$ apart, each divided into 2 replicates $(1 \mathrm{~m} \times 1 \mathrm{~m})$ that were several meters apart. For each tree species, 40 bags were prepared: 5 blocks $\times 2$ replicates $\times 4$ retrieval dates. A possible HFA effect was assessed by incubating single-species litters of the two dominant species (G. dewevrei and S. zenkeri for monodominant and mixed forests, respectively) under monodominant forests with the same design ( 5 blocks and 2 replicates per block). Finally, to test for possible interacting effects among litters, mixedspecies litterbags corresponding to all two-way combinations of the tree species $(n=28)$ were incubated in one replicate per block under mixed forests; for every litter mixture, 10 bags were prepared: 5 blocks $\times 2$ retrieval dates.

All litterbags were placed on the forest floor in September 2014 (at the end of the dry season, when forest floor litter mass was highest) and were attached to the forest floor by metal pins to prevent movement. Single-species litterbags were retrieved after 1,2, 3 and 6 months and mixed-species litterbags after 1 and 6 months (Powers et al. 2009). After collection, litterbags were air-dried and litter was removed from each litterbag. Adhered debris were removed and litter was rinsed off with water to remove adhering sand particles. The contents of mixed-species litterbags were separated by species to assess individual species mass loss in mixture. Litter were oven-dried at $65^{\circ} \mathrm{C}$ during $48 \mathrm{~h}$ and weighed.

\subsection{Calculations and statistical analysis}

From the litterbag experiment, leaf litter decomposition was characterised by calculating the relative remaining mass of leaf litter (RM, \%) at each collection date:

$\mathrm{RM}=\frac{m_{t}}{m_{0}} \times 100$

where $m_{t}$ indicates the remaining dry mass of litter at the collection date $t$ and $m_{0}$ is the dry mass of litter initially introduced in the litterbags. For mixed-species litterbag, RM was also calculated for each litter component separately.

We then analysed the temporal trends in RM for singlespecies litterbags and tested the various hypotheses presented in the introduction. First, the effect of litter quality on RM was tested. Second, we determined the extent to which the mixedspecies RM can be predicted based on the additive effect of single-species RM and tried to explain the remaining variability based on the incubation time, chemical dissimilarity and the mixture identity.

For the single-species litterbags, RM was modelled by tree species as a function of incubation time using the following model in which the decay rate is time dependent (Feng and $\mathrm{Li}$ 2001; Manzoni et al. 2012):

$\mathrm{RM}=e^{-\left(\frac{t}{b}\right)^{a}} \times 100+\varepsilon$

with $a$ and $b$ parameters describing the shape of the curve and $\varepsilon$ is the error term. Temporal autocorrelation was accounted for in our model through a first-order autoregressive correlation structure. Contrary to the single exponential model developed by Olson (1963) using a constant decay rate over the decomposition period, the form of Eq. 2 allows the decay rate to change (increase and decrease) with incubation time according to the decomposition processes. Based on Eq. 2, the 
instantaneous and apparent decay rate $k_{\text {app }}$, expressed as month $^{-1}$ (Manzoni et al. 2012) can be computed as:

$k_{\mathrm{app}}=\frac{a}{b} \times\left(\frac{t}{b}\right)^{a-1}$

Given the high correlation between the nutrient concentrations of leaf litter (Baraloto et al. 2010; Verbeeck et al. 2014), the litter quality was characterised using a principal component analysis (PCA) with 11 foliar litter traits (C, Ca, cellulose, $\mathrm{K}$, lignin, Mg, Mn, N, P, S, Si litter concentrations). Lignin:N $(\mathrm{L}: \mathrm{N}), \mathrm{C}: \mathrm{N}, \mathrm{C}: \mathrm{P}, \mathrm{C}: \mathrm{S}$ and N:P ratios were included as supplementary variables and did not affect the PCA. Initial nutrient concentrations of mixed leaf litters were calculated as the average concentration of its component species, and the positions of the different litter mixtures were also included as supplementary individuals. Given the high proportion of the variance explained by the first PCA axis, initial litter chemistry was characterised based on the scores of the first PCA axis. In order to assess how green and leaf litter traits are associated, a PCA analysis was also conducted with green leaves physical and chemical traits (SLA and $\mathrm{C}, \mathrm{Ca}$, cellulose, $\mathrm{K}$, lignin, $\mathrm{Mg}$, Mn, N, P, S, Si litter concentrations), and the latter was used to derive a proxy of the 'leaf economics spectrum scores' (Wright et al. 2004). Due to the different units and the contrasted magnitude among the traits, both PCA were performed on mean-centred and scaled variables.

We used linear regressions to determine how well initial litter chemistry can predict RM from single-species and mixed-species litterbags under mixed forests.

For the same collection time, the observed RM of mixedspecies litterbags was related to the expected one calculated based on the RM of the corresponding single-species litterbags. As tree species were in equal proportions in the mixtures, the expected RM of the whole mixture was the average of the expected RM of the two leaf litter components. This first step allowed us to determine which proportion of the variability can be explained by simple additive effects through the $R^{2}$ of the additive model obtained from Eq. 4 .

$R_{\mathrm{AM}}^{2}=\frac{\mathrm{SS}_{\mathrm{reg}}}{\mathrm{SS}_{\mathrm{tot}}}$

Where $R_{\text {AM }}^{2}$ is the $R^{2}$ of the additive model (1:1 line between expected and observed $\mathrm{RM}$ ), $\mathrm{SS}_{\text {reg }}$ is the regression sum of square (expected RM against mean of observed $\mathrm{RM}$ ) and $\mathrm{SS}_{\text {tot }}$ is the total sum of square (observed RM against their average).

Then, we tried to determine the factors affecting the remaining variability. According to Eq. 5, we calculated the deviation between the expected and observed RM of mixedspecies litterbags under mixed forests for the whole mixture $\left(\mathrm{DERM}_{\mathrm{m}}\right)$ or for the target species alone within mixed-species litterbags $\left(\mathrm{DERM}_{\mathrm{t}}\right)$. In the mixed litterbags, the component species were separated into target and neighbouring species.
In order to detect an eventual non-additive effect on the mixture decomposition, $\mathrm{DERM}_{\mathrm{m}}$ was tested against 0 ( $t$ test). We used an analysis of variance (type I) to test for the effects of incubation time, chemical dissimilarity between mixture components, mixture identity $(n=28)$ and their interactions.

$\mathrm{DERM}_{\mathrm{m}}=\mathrm{RM}_{\text {expected }}-\mathrm{RM}_{\mathrm{obs}}$

Negative $D_{E R M}$ values suggest antagonistic responses (decreasing litter breakdown), whereas positive values refer to synergistic responses (acceleration of litter decomposition). Chemical dissimilarity between component species of the mixture was measured as the Euclidian distance between two species in the plot of the two first factorial axes.

Further, the influence of the same variables was tested on the deviation from the expected RM of each component species of the mixture $\left(D_{E R M}\right)$ through an analysis of variance (type I) also involving the litter quality of the target species.

We calculated the additional decomposition at home (ADH) for G. dewevrei and S. zenkeri which represents the percentage by which the decomposition process is sped up or slowed down at home, as:

$\mathrm{ADH}=\frac{\mathrm{RM}_{\text {in situ }}-\mathrm{RM}_{\text {ex situ }}}{\mathrm{RM}_{\text {in situ }}} \times 100$

A negative value of ADH indicates HFA (home-field advantage for litter decomposition) and a positive value of ADH means HFD (home-field disadvantage for litter decomposition). Additionally, we investigated the effects of forest type, incubation time, tree species and their interactions on litter mass loss for both dominant species (S. zenkeri and G. dewevrei under mixed and monodominant forests, respectively) using an analysis of variance (type I).

All statistical analyses were performed in $\mathrm{R}$ version 3.2.0.

\section{Results}

\subsection{Temporal pattern of litter decomposition}

After 6 months of incubation in single-species litterbags, RM amounted from 27.18 (G. thompsonii and S. zenkeri) to $56.44 \%$ (G. dewevrei; Fig. 2a). The highest mass loss occurred during the first month of decomposition where mass loss varied between 5.88 and $38.24 \%$, for $G$. dewevrei and S. zenkeri, respectively. Litter mass loss strongly decreased along with time, from $19.47 \%$ on average after 1 month down to $6.98 \%$ (ranging from 5.62 and $7.71 \%$ ) per month on average between the 3rd and the 6th months (for species-specific RM time-dependent models, see Fig. 7 in the Appendix). Ranges of remaining mass from mixed-species litterbags are similar to those reported in singlespecies litterbags. RM varied from 54.85 ( $G$. thompsonii + S. zenkeri) to $96.53 \%$ (P. oxyphylla $+C$. hankei) after 1 month 


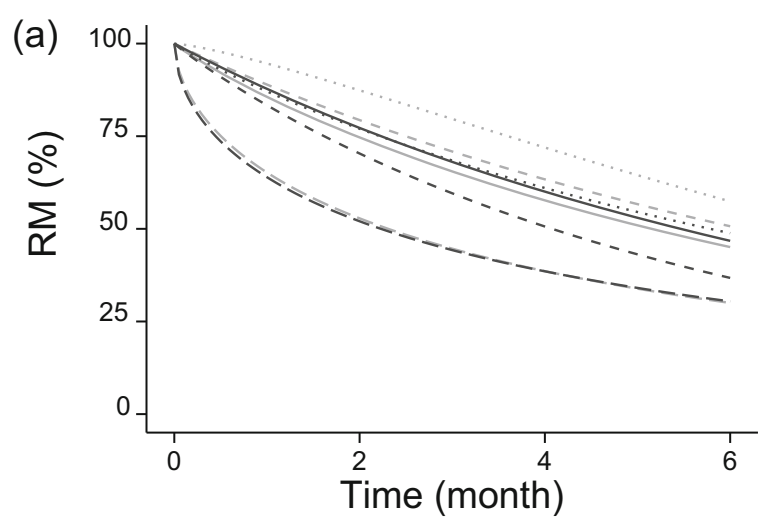

Fig. 2 a Remaining mass (RM) and $\mathbf{b}$ apparent decay rates $\left(k_{\text {app }}\right)$ of single-species litterbags under mixed forests as a function of time. Apparent decay rates were calculated using $k_{\mathrm{app}}=(a / b) *(t / b)^{(a-1)}$ where parameters $(a, b)$ were adjusted based on the relationship

and from 27.69 (G. thompsonii + P. suaveolens) to $60.68 \%$ (G. dewevrei $+C$. hankei) after 6 months.

The highest decay rates $\left(k_{\text {app }}\right)$ during the first month of decomposition were found for by $S$. zenkeri and G. thompsonii (0.24 and 0.25 month $^{-1}$, respectively), but this rate decreased quickly and reached values of 0.11 and 0.12 month $^{-1}$ after 6 months for $S$. zenkeri and G. thompsonii, respectively (Fig. 2b). Moderate decay rates were found for by $P$. suaveolens, A. mannii, J. seretii, P. oxyphylla and C. hankei $(0.17,0.14$, $0.13,0.13$ and 0.11 month $^{-1}$, respectively) and remained relatively stable over the duration of the experiment. The decay rate of $G$. dewevrei was initially the lowest and then stabilised around that of the other tree species after 6 months. After 6 months of decomposition, decay rates were stabilising around 0.12 month $^{-1}$, except for P. suaveolens lying at 0.16 month $^{-1}$. Decay rates differed significantly among species at 1,2 and 3 months (ANOVA for $t=1$ : $F=11.54 ; P<10^{-5}$ ) but difference decreased with time; decay rate did not vary significantly between species after 6 months (ANOVA for $t=6: F=0.828$; $P=0.56$ ).

\subsection{Chemical controls on litter decomposition}

Across the studied species, a wide variability in initial leaf litter traits was observed (see Table 4 in the Appendix). For example, Mn concentrations varied 120 -fold among tree species, from 0.03 ( $G$. dewevrei) to $3.57 \mathrm{mg} \mathrm{g}^{-1}$ (P. oxyphylla) and $\mathrm{K}$ concentrations varied 9-fold, from 2.58 (P. oxyphylla) to $24.09 \mathrm{mg} \mathrm{g}^{-1}$ (G. thompsonii). Differences from 2- to 8-fold were observed for the other leaf litter nutrient concentrations.

The first two axes of the PCA explained $67.1 \%$ of the variability in the 11 leaf litter traits among the eight tree species involved in the decomposition experiment (Fig. 3a). The first axis accounted for the large majority of this explained variability (48.6\%) and was positively related to litter $\mathrm{Ca}, \mathrm{K}$, $\mathrm{Mg}, \mathrm{N}, \mathrm{P}$ and $\mathrm{S}$ concentrations and negatively related to $\mathrm{C}$, lignin and Si concentrations. The second axis explained an additional $18.5 \%$ of the variability in traits and was positively related to cellulose and $\mathrm{Mn}$ concentrations.

C. hankei, G. dewevrei, J. seretii and P. oxyphylla were found at the left side of the first PCA axis and therefore exhibited lower nutrient concentrations and higher lignin concentration (Fig. 3b). G. dewevrei had the lowest N, Ca, K, P, $\mathrm{Mn}$ and $\mathrm{Mg}$ but the highest $\mathrm{Si}$ litter concentrations. A. mannii, G. thompsonii, P. suaveolens and S. zenkeri were found at the right side of the first PCA axis and showed higher $\mathrm{Ca}, \mathrm{K}, \mathrm{Mg}$, $\mathrm{N}, \mathrm{P}$ and S concentrations. S. zenkeri exhibited the highest N, $\mathrm{Ca}, \mathrm{Mg}$ and $\mathrm{S}$ litter concentrations. G. thompsonii was associated with the highest $\mathrm{K}$ and $\mathrm{P}$ concentrations and the lowest lignin fraction as well as the lowest $\mathrm{N}: \mathrm{P}$ and lignin:N ratios.

The eight species exhibited similar patterns along the two first axes of the PCA performed with the green leaf traits which respectively accounted for 55.5 and $26.7 \%$ of the variability (see Fig. 8 in the Appendix). Higher nutrient concentrations and SLA were reported for the green leaves of A. mannii, G. thompsonii, P. suaveolens and S. zenkeri, while C. hankei, G. dewevrei, J. seretii and P. oxyphylla showed higher $\mathrm{C}$ concentrations.

As shown by the linear regression model reported in Fig. 4, more than $90 \%$ of the variation in remaining mass from both single- and mixed-species litters over the entire incubation period under the mixed forests was explained by the litter chemical quality, as assessed by the position of each litter along the first PCA axis performed with litter traits (Fig. 3). For each studied period, the remaining mass strongly decreased with the position along the first PCA axis (Fig. 4). Therefore, the remaining mass exhibited by the four species situated at the right side of the PCA (A. mannii, G. thompsonii, $P$. suaveolens and $S$. zenkeri) was found to be lower compared to that of the four species located at the left side ( $C$. hankei, G. dewevrei, J. seretii and P. oxyphylla). After 1 month of incubation, the difference between the intercept $(P<0.01)$ 

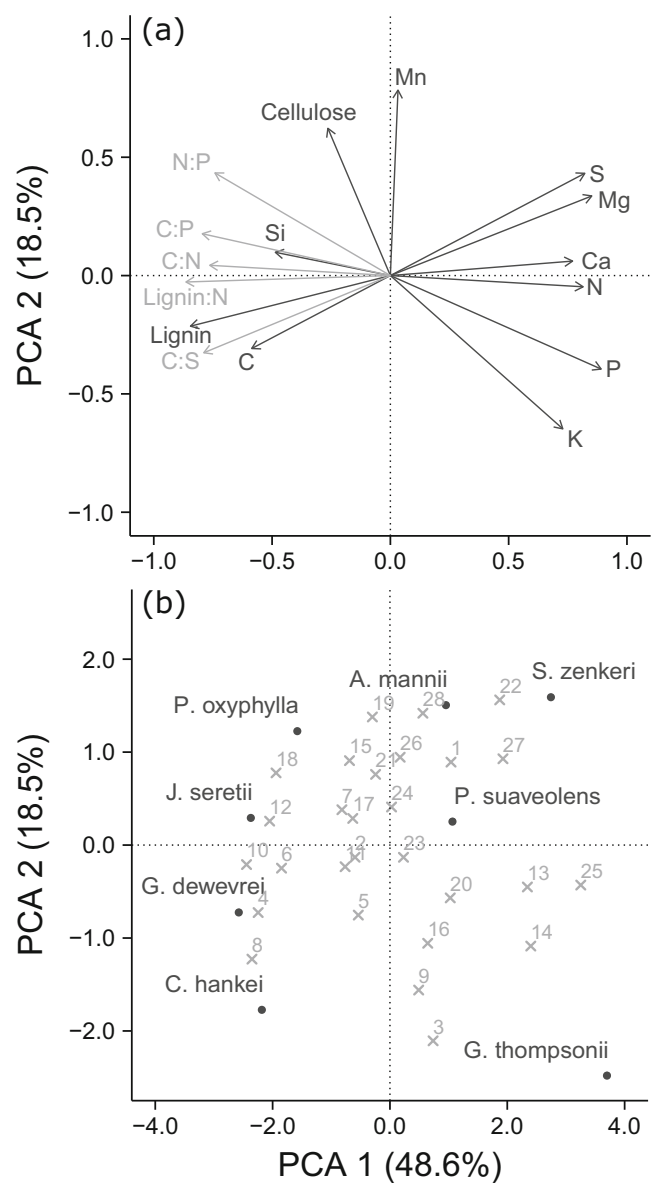

Fig. 3 Principal component analysis of 11 leaf litter traits of eight tropical tree species (black points). Projection of a variables and $\mathbf{b}$ species on the first two axes. Eigenvalue of axis 1 and axis 2 is 5.35 and 2.03, respectively, explaining 48.6 and $18.5 \%$ of the variation, respectively. Chemical concentrations included as active variables in the analysis (black arrows): C, Ca, K, Mg, Mn, N, P, S, Si, cellulose and lignin litter concentrations. Chemical traits included as illustrative variables (grey arrows): C:N, C:S, C:P, N:P and lignin:N litter ratios. The positions of the mixed-species litterbags (from 1 to 28 , see Table 5 in the Appendix) are included as supplementary individuals

for mixed-species (78.79) compared to single-species litterbags (81.35) was significant, yet weak, whereas a similar slope was reported (Fig. 4). Conversely, after 6 months, a similar intercept was found, while mixed-species litterbags exhibited slightly but significantly lower impact of litter quality (slopes of -4.19 and -3.39 , respectively for single-species and mixed-species litterbags, $P$ value of $t$ test $<0.05$ ). For both single-species and mixed-species litterbags, intercepts strongly decreased with time.

Variation in remaining mass was also significantly associated with single leaf litter traits after all four retrievals (see Fig. 9 in the Appendix). Using similar linear regression models, initial leaf litter $\mathrm{Ca}$ concentration was found to have the greatest relation among single traits $\left(R^{2}=0.89 ; P 10^{-10}\right)$, followed by $\mathrm{P}$ concentration $\left(R^{2}=0.87 ; P<P 10^{-10}\right)$, S concentration $\left(R^{2}=\right.$ $\left.0.86 ; P<10^{-10}\right)$ and $\mathrm{N}$ concentration $\left(R^{2}=0.84 ; P<P 10^{-10}\right)$.
Remaining mass was also significantly related to other single leaf litter traits $(\mathrm{C}$, cellulose, $\mathrm{N}, \mathrm{K}$, lignin, $\mathrm{Mg}, \mathrm{Mn}$ and $\mathrm{Si}$ concentration and $\mathrm{C}: \mathrm{N}$, lignin: $\mathrm{N}, \mathrm{C}: \mathrm{S}$ and $\mathrm{N}: \mathrm{P}$ ratios). Species and litter mixture with a higher initial litter $\mathrm{C}$, lignin and $\mathrm{Si}$ concentration and higher ratios generally decomposed slower (i.e. had more mass remaining). In contrast, the slope of the regression of remaining mass on initial litter nutrient $(\mathrm{N}, \mathrm{K}$, $\mathrm{Mg}, \mathrm{Mn}$ ) concentration was negative, indicating that litter of species with higher initial litter nutrient concentrations decomposed faster (i.e. had less remaining mass).

\subsection{Litter mixing effects on remaining mass}

As shown by Fig. 5, observed RMs were strongly related to expected RMs based on the single-species decomposition experiment $\left(R^{2}\right.$ of 86 and $69 \%$, respectively after 1 and 6 months of incubation). These relationships were tested against the 1:1 line and results varied with incubation time. After 1 month of incubation, the slope (1.04) was not significantly $(P=0.85)$ different from 1 , while the intercept $(-5.99)$ was significantly lower than $0\left(P<10^{-2}\right)$, indicating a leaf litter decomposition faster than expected. After 6 months, the slope $(0.78)$ and the intercept (10.12) were significantly different from $1\left(P<10^{-2}\right)$ and $0\left(P<10^{-3}\right)$, respectively. This shows that, for the mixedspecies litterbags decomposing faster, decomposition was a bit slower than expected, while the mixed-species litterbags decomposing more slowly did not depart from expectation. Through the 1:1 line, we showed that additive effect explained 86 and $69 \%$ of the variability in the reported mixed litter decomposition after 1 and 6 months, respectively.

The variability in the mixed litter decomposition not explained by additive effects was then analysed based on the $\mathrm{DERM}_{\mathrm{m}}$ which ranged from -10.0 to $9.3 \%$ and from -12.8 to $7.5 \%$ after 1 and 6 months, respectively. $\mathrm{DERM}_{\mathrm{m}}$ changed with incubation time; $\mathrm{DERM}_{\mathrm{m}}$ first showed significant synergistic mixing effect after 1 month (mean DERM $\mathrm{m}_{\mathrm{m}}$ across all 28 mixture types $+2.56 \%, P<10^{-5}$ ), while after 6 months of incubation, mixing effect became slightly but significantly antagonistic (mean DERM $_{\mathrm{m}}$ across all 28 mixture types $0.86 \%, P=0.02$ ). Indeed, analysis of variance (ANOVA) showed that $\mathrm{DERM}_{\mathrm{m}}$ significantly $(P<0.001)$ varied with incubation time, mixture identity, their interaction and the interaction between chemical dissimilarity and incubation time (Table 1). Negative interaction between chemical dissimilarity and incubation time suggests that chemical dissimilarity effect on DERM $_{\mathrm{m}}$ was strongly time dependent, despite the nonsignificant main effect $(P=0.13)$. Indeed, the impact of chemical dissimilarity was first positive after 1 month of incubation but became negative after 6 months of incubation.

The separation of litter from individual species included in the mixtures at the final collection date allowed us to test for mixture effects on decomposition of individual species within mixtures through DERM $\mathrm{t}_{\mathrm{t}}$. The deviation from expected RM $\left(\mathrm{DERM}_{\mathrm{t}}\right)$ of 
Fig. 4 Remaining mass under mixed forests after 1 (a), 2 (b), 3 (c) and 6 (d) months for eight tropical tree species (singlespecies litterbags, in black) and all their two-way combinations (mixed-species litterbags in grey, from 1 to 28, see Table 5 in the Appendix) as a function of litter quality described by the position along the PCA1. Parameter estimates for the linear regression model $\left(\mathrm{RM}=\alpha_{\mathrm{t}, \mathrm{C}}+\beta_{\mathrm{t}, \mathrm{C}} * \mathrm{PCA} 1\right.$, where coefficients are allowed to vary with time and litterbag diversity) are given in the captions, $R^{2}=0.91\left(P<10^{-16}\right)$ a)

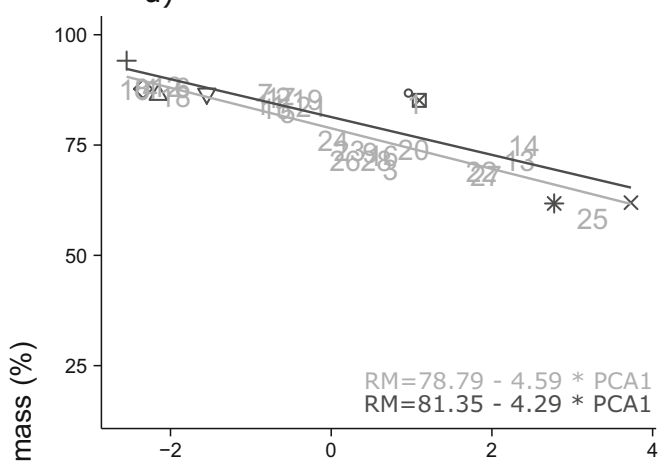

c)

है

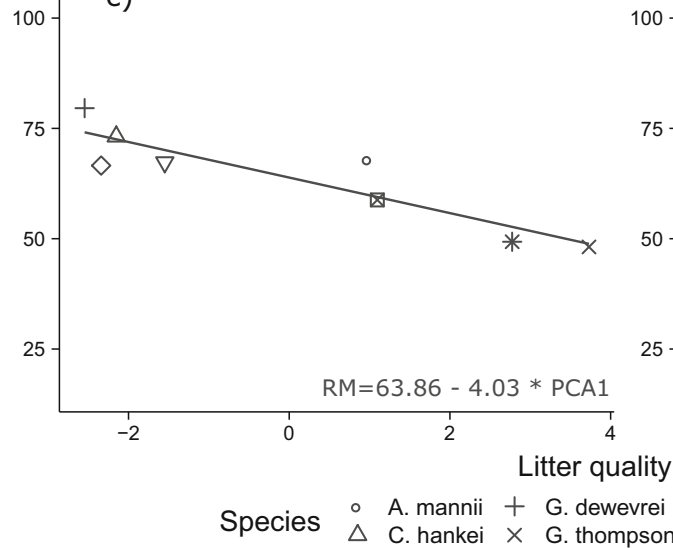

b)

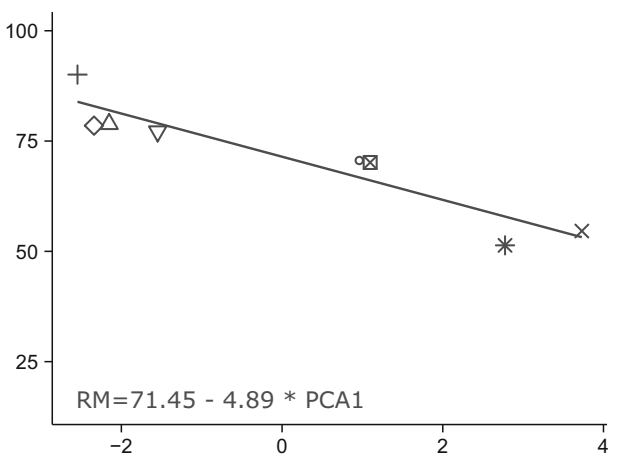

d)

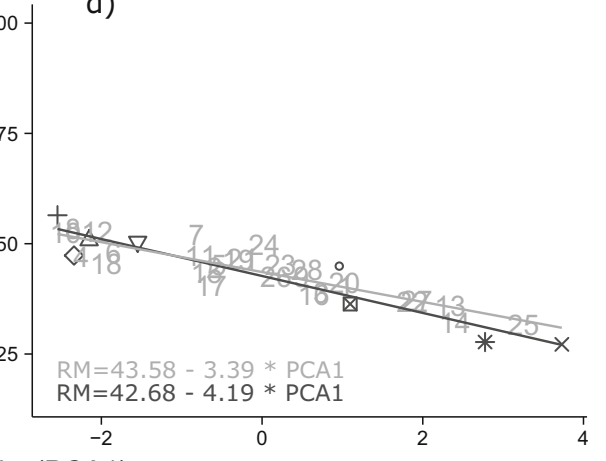

A.

species within mixtures ranged from -25.65 to $20.98 \%$ and from -18.73 to $14.11 \%$ after 1 and 6 months of incubation under mixed forests, respectively. The ANOVA investigating the role of incubation time, chemical dissimilarity between mixture components, mixture identity $(n=28)$, target species litter quality and their interactions explained 33.9\% in $\mathrm{DERM}_{\mathrm{t}}$ variation. The mixture identity (i.e., species composition of mixtures), incubation time and their interaction and the interaction between time and the target litter quality had a significant influence $\left(P<10^{-3}\right)$ on $\mathrm{DERM}_{\mathrm{t}}$ in mixtures, while the litter quality alone did not significantly influence $\mathrm{DERM}_{\mathrm{t}}$ (Table 2). Chemical dissimilarity of the mixture interacted significantly and negatively with litter quality of the target, suggesting that the better was the litter quality of the target species the weaker was the chemical dissimilarity influence on $\mathrm{DERM}_{\mathrm{t}}$. The significant mixture identity effect showed that $\mathrm{DERM}_{\mathrm{t}}$ of certain target species in mixed-species litterbags differed between mixture types; in addition, this influence varied with time as reported by the significant interaction between time and mixture identity.

\subsection{Home-field advantage}

For both G. dewevrei and S. zenkeri, decomposition was significantly faster at home than away during the early stage of decomposition. Indeed, as shown by Fig. 6, we found significant negative $\mathrm{ADH}$ after 1 month $(-8.63 \pm 2.18$ and $-9.40 \pm$
$2.25 \%$ for $S$. zenkeri and G. dewevrei, respectively) and 2 months $(-17.85 \pm 2.71$ and $-9.02 \pm 1.66 \%$ for $S$. zenkeri and $G$. dewevrei, respectively) which suggests an HFA. At 3 months, there was no significant impact of the incubation environment for any of the species, while at 6 months, only $S$. zenkeri showed a significant HFA $(-11.85 \pm 1.81 \%)$.

These results were confirmed by the ANOVA of remaining mass (Table 3), with forest type, incubation time, species and their interactions as fixed factors. Remaining mass of $G$. dewevrei and $S$. zenkeri was significantly related to incubation time, tree species (i.e. G. dewevrei vs. S. zenkeri leaf litters) and to the interaction between forest type and tree species. There was no main Forest type effect; instead, the effect of forest type differed between species as shown by the significant interaction term.

\section{Discussion}

\subsection{Temporal dynamics and interspecific variation of litter decay}

Under mixed forests, the average litter decay rates across tree species decreased to 0.12 month $^{-1}$ after 6 months and the litter mass loss in 6 months amounted to 57\%. As expected, these values are higher than the decomposition rate reported for 


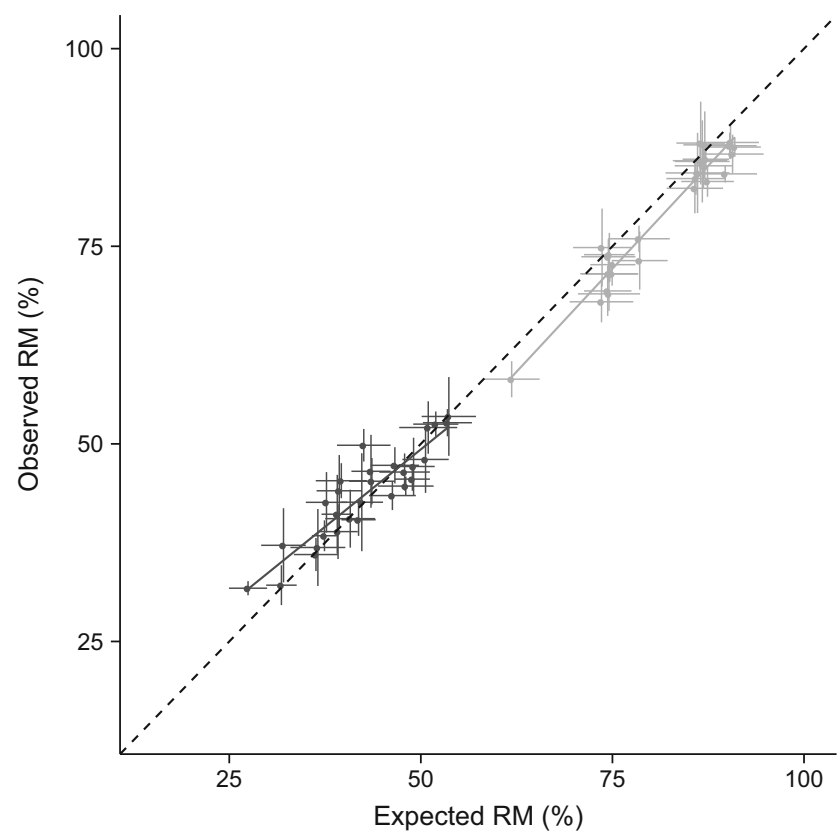

Fig. 5 Observed RM against expected RM for mixed-species litterbags based on simple additive effects, after 1 (in grey) and 6 (in black) months under mixed forests. Horizontal and vertical error bars show \pm 1 standard deviation. The dotted lines indicate the 1:1 line along which observed and predicted values are equal. $R^{2}$ of fitted lines: ( 1 month, in grey) 0.86 $\left(P<10^{-16}\right)$ and $\left(6\right.$ months, in black) $0.69\left(P<10^{-16}\right)$

temperate forests but similar to the range of $0.04-0.32$ month $^{-1}$ (mean value of 0.19 month $^{-1}$ ) observed in tropical forests for the same incubation period (Aerts 1997; Hättenschwiler et al. 2011; Waring 2012). The greatest mass losses were reported for $S$. zenkeri and G. thompsonii with 72 and $73 \%$ of mass loss after 6 months of incubation, respectively. In contrast, $G$. dewevrei exhibited the lowest decomposition rate with $43 \%$ of mass loss after 6 months of incubation. The limited mass loss of $G$. dewevrei under mixed forests observed in this study (6,10 and 20\% after 1,2 and 3 months, respectively) is consistent with the range of mass losses reported in previous studies (Torti et al. 2001; Peh et al. 2012). Several studies suggest that the slow litter decomposition of $G$. dewevrei, by

Table 1 Factors explaining the non-additive component of the litter mixture effect. Significance of the effects of incubation time (1 vs. 6 months), chemical dissimilarity between component species, mixture inhibiting the establishment of small-seeded species and causing a low $\mathrm{N}$ availability, is a key part of its dominance strategy (Hart et al. 1989; Peh et al. 2011). In addition, Cassart et al. (2017) have shown that larger soil (forest floor and mineral soil) carbon accumulation under monodominant forests compared to adjacent mixed forests can be inferred from the low decomposition rate of $G$. dewevrei.

While the decomposition rate of $S$. zenkeri and $G$. thompsonii slowed down with time, no significant change over time in the decay rates of A. mannii, C. hankei, J. seretii, $P$. oxyphylla and $P$. suaveolens was observed. Decay rate generally decreases with time due to changes in substrate composition (such as increasing lignin concentration and decreasing cellulose concentration) explained by the selective consumption of some organic components by microbes (Berg and McClaugherty 2014) and by the leaching of soluble compounds. Regarding our litterbag incubation experiment, the decrease in decay rate could also be ascribed to the expected reduced rainfall during the last 2 months of the experiment. Based on the average meteorological data collected in Yangambi (100 km to the west of Kisangani), we may indeed expect high precipitations in the early phase of incubation (from September to December) with a maximum of $321 \mathrm{~mm}$ in November 2014 but more limited rainfall (below $60 \mathrm{~mm}$ ) in January and February (Fig. 1). During the course of decomposition, $G$. dewevrei litter showed an initial time lag of 3 months during which the $k_{\text {app }}$ value was limited to 0.10 month $^{-1}$ and then slightly increased up to 0.12 month $^{-1}$ (Fig. 2b). This slow initial decomposition rate is probably due to the delay in colonisation and establishment of microbial community which is reinforced by the relatively high concentrations of recalcitrant phenolic compounds (Freschet et al. 2012a; Cornwell and Weedon 2014).

\subsection{Leaf litter traits predicting decomposition rate}

The variation in RM during all stages of decomposition was strongly associated with chemical differences in overall litter

identity (see Table 5 in the Appendix) and their interactions on the deviation from the expected remaining mass of litter in mixed-species litterbags under mixed forests

\begin{tabular}{lrcccc}
\hline Source & $d f$ & Sum squares & $\%$ sum squares & $P$ value & Effect on DERM $_{\mathrm{m}}$ \\
\hline Time & 1 & 821.0 & 17.6 & $<0.001$ & $\downarrow$ \\
Chemical dissimilarity & 1 & 22.3 & 0.5 & $<.13$ & $(\uparrow)$ \\
Mixture identity & 26 & 583.7 & 12.5 & $<0.001$ & na \\
Time $\times$ chemical dissimilarity & 1 & 173.0 & 3.7 & $<0.001$ & $\downarrow$ \\
Time $\times$ mixture identity & 26 & 867.9 & 18.6 & $<0.001$ & na \\
Residuals & 224 & 2193.1 & 47.1 & & \\
\hline
\end{tabular}

$\downarrow$ and $\uparrow$ denote a negative or a positive influence on $D E R M_{m}$, respectively. Negative $D_{E R M}$ values suggest antagonistic responses (decreasing litter breakdown), whereas positive values refer to synergistic responses (acceleration of litter decomposition). The direction of the relationship with categorical variable is not applicable (na) 
Table 2 Results of the ANOVA describing the factors affecting the deviation from the expected remaining mass of target species litter within mixed-species litterbags. Significance of the incubation time, chemical dissimilarity between component species and target species leaf litter quality (described by its position along the first PCA axis, cf. Fig. 3), mixture identity (see Table 5 in the Appendix) and their interactions

\begin{tabular}{lrcccc}
\hline Source & $d f$ & Sum squares & \% sum squares & $P$ value & $\begin{array}{l}\text { Effect on }_{\text {DERM }_{\mathrm{t}}} \\
\end{array}$ \\
\hline Time & 1 & 1655.9 & 8.2 & $<0.001$ & $\downarrow$ \\
Chemical dissimilarity & 1 & 546.7 & 2.7 & $<0.001$ & $\uparrow$ \\
Target quality & 1 & 76.9 & 0.4 & 0.09 & $(\downarrow)$ \\
Mixture identity & 26 & 1168.7 & 5.8 & $<0.001$ & na \\
Time $\times$ chemical dissimilarity & 1 & 559.1 & 2.8 & $<0.001$ & $\downarrow$ \\
Time $\times$ target quality & 1 & 433.8 & 2.1 & $<0.001$ & $\uparrow$ \\
Time $\times$ mixture identity & 26 & 1650.4 & 8.2 & $<0.001$ & na \\
Chemical dissimilarity $\times$ target quality & 1 & 754.0 & 3.7 & $<0.001$ & $\downarrow$ \\
Residuals & 501 & $13,361.1$ & 66.1 & & \\
\hline
\end{tabular}

$\downarrow$ and $\uparrow$ denote a negative or a positive influence on $D E R M_{t}$, respectively. Negative $\mathrm{DERM}_{\mathrm{t}}$ values suggest antagonistic responses (decreasing litter breakdown), whereas positive values refer to synergistic responses (acceleration of litter decomposition). The direction of the relationship with categorical variable is not applicable (na) quality (Fig. 4), as quantified by the tree species position along the PCA1. This position was in turn strongly related to that on the first axis of the green leaf PCA $\left(P<10^{-3}\right.$, see Fig. 10 in the Appendix), which suggests that those leaf litter traits closely inform on the leaf economics spectrum (LES). The LES describes strong relationships between multiple functional leaf traits, which reflect contrasting species strategies for carbon gain and growth (Reich et al. 1997; Wright et al. 2004). In the present case, A. mannii, G. thompsonii, $P$ suaveolens and $S$. zenkeri, which are all located at the right end on our proxy of LES (Fig. 3), appear to be fast-growing species that produce short-lived and structurally inexpensive leaves with a high nutrient content and a high photosynthetic rate (Wright et al. 2004; Poorter and Bongers 2006; Osnas et al. 2013). By contrast, the position of C. hankei, G. dewevrei, J. seretii and $P$. oxyphylla at the left end on our proxy of LES indicates

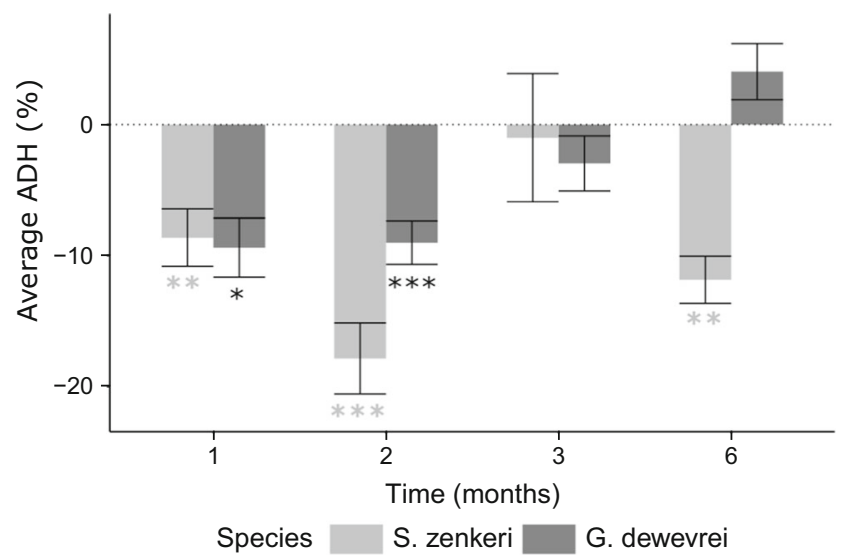

Fig. 6 Magnitude and direction of litter-site interactions, expressed as the average additional decomposition at home (ADH) for G. dewevrei (in black) and $S$. zenkeri (in grey) for each incubation period. Error bars indicate standard errors. $*, * *$, and $* * *$ denote respectively significant difference from zero at $P<0.05, P<0.01$ and $P<0.001$. A negative value of ADH indicates HFA (home-field advantage) and a positive value of ADH means HFD (home-field disadvantage) slow-growing species that produce long-lived, low-quality leaves (nutrient poor and high lignin concentration) at highenergy costs with lower photosynthetic capacity. These two groups of species show a trade-off between fast growth-high photosynthesis and slow growth-persistent, long-lived leaves (Shipley et al. 2006). Species with fast acquisitive leaf traits show higher decomposition rates than species with slow conservative traits, which is consistent with previous studies (Santiago 2007; Bakker et al. 2011).

While litter decay rate was best predicted by a multivariate measure of litter quality, individual leaf litter traits such as $\mathrm{Ca}$, $\mathrm{S}, \mathrm{P}, \mathrm{N}, \mathrm{K}$, lignin and $\mathrm{Mg}$ concentrations or $\mathrm{C}: \mathrm{S}$, lignin: $\mathrm{N}, \mathrm{C}: \mathrm{P}$, $\mathrm{C}: \mathrm{N}$ and $\mathrm{N}: \mathrm{P}$ ratios were also closely related.

As expected, high nutrient concentrations tend to enhance litter decomposition. The strongest relationship between individual trait and decay rate was observed for Ca concentration. As an important constituent of fungal cell walls and of certain arthropods' exoskeleton, these decomposer organisms need high amounts of $\mathrm{Ca}$ in their diets (Swift et al. 1979; Lovett et al. 2016). In addition, high concentrations of cations such as $\mathrm{Ca}$ and $\mathrm{Mg}$ in leaf litter make it less acidic and therefore more palatable for decomposer organisms (Cornelissen et al. 2003).

Table 3 Results of the ANOVA testing the home-field advantage hypothesis. Significance of the effects of incubation time (after 1, 2, 3 and 6 months of incubation), forest type (mixed vs. monodominant forests), tree species ( $S$. zenkeri and $G$. dewevrei) and their interactions on the litter remaining mass from single-species litterbags

\begin{tabular}{lrrrc}
\hline Source & $d f$ & Sum squares & $\%$ sum squares & $P$ value \\
\hline Time & 3 & 29,715 & 41.0 & $<0.001$ \\
Forest & 1 & 66 & 0.1 & 0.16 \\
Species & 1 & 36,668 & 50.6 & $<0.001$ \\
Time $\times$ forest & 3 & 83 & 0.1 & 0.47 \\
Forest $\times$ species & 1 & 488 & 0.7 & $<0.001$ \\
Residuals & 166 & 5413 & 7.5 & \\
\hline
\end{tabular}


However, in order to investigate the involvement of decomposer organism in this positive relation with $\mathrm{Ca}$ concentration, further experiments are required.

Leaf $\mathrm{P}$ concentration was a better predictor of litter decay rate than $\mathrm{N}$ concentration $\left(R^{2}\right.$ of 0.47 and 0.64 for the relationships between decay rates and $\mathrm{N}$ and $\mathrm{P}$ concentrations, respectively). While $\mathrm{N}$ availability is an important driver of decomposition rate in temperate forests, $\mathrm{P}$ is frequently the most limiting nutrient in tropical rainforests with several impacts on ecosystem processes such as litter decomposition (Vitousek 1984; Cleveland et al. 2002; Hättenschwiler et al. 2011). Limitation of decomposition rates by N, S or P is also indicated by the significant negative effect of $\mathrm{C}: \mathrm{N}, \mathrm{C}: \mathrm{P}, \mathrm{C}: \mathrm{S}$, $\mathrm{N}: \mathrm{P}$ and lignin:N ratios on decay rates. Higher $\mathrm{C}: \mathrm{N}, \mathrm{C}: \mathrm{P}, \mathrm{C}: \mathrm{S}$, $\mathrm{N}: \mathrm{P}$ and lignin:N ratios are clear indication of lower N, P and $\mathrm{S}$ availability inducing lower use efficiency of decomposers community (Zhang et al. 2008).

High cellulose and Si litter concentrations tended to decrease litter mass loss. Cellulose, another major cell-wall constituent well-known to reduce litter decomposition rate, is expected to have a great impact in a similar way as lignin (McClaugherty and Berg 1987). In cell walls, Si also plays a role in mechanical defence against fungi and herbivores leading to a reduced mass loss (Reynolds et al. 2009).

As a cofactor of the enzyme manganese peroxidase, $\mathrm{Mn}$ has been shown to enhance lignin degradation (Berg et al. 2007; Berg 2014; Keiluweit et al. 2015) and is therefore expected to exhibit the greatest influence in late stages of litter decomposition. Therefore, longer incubation period would be needed to detect the influence of Mn litter concentrations.

\subsection{Direct litter mixing effect on decomposition}

The variability in decomposition rate of litter mixtures can result from both additive and non-additive effects (positive or negative). Our experiment assessed litter mixture effects on decomposition along litter dissimilarity gradients generated by assembling the full set of 28 pairwise species combinations that can be derived from a pool of eight species in a common litter matrix associated with mixed forests. Simple additive effect explained large part of the variability reported in litter mixture decomposition (86 and 69\% after 1 and 6 months of incubation, respectively; Fig. 5).

Mixing litter lead to weak but significant effect after 1 and 6 months. Our results indicate that litter decomposition under mixed forests should be highly predictable with knowledge of species composition and species-specific decomposition rates (see Figs. 4 and 5). On average, we reported synergistic effect of mixing after 1 month of incubation and antagonistic after 6 months. After both incubation periods, no mixed-species litterbags decomposed faster than the fastest single-species litter treatment ( $G$. thompsonii) or less rapidly than the slowest single litter treatment (G. dewevrei).
Time, mixture identity and their interaction were the most important factors explaining variation in $\mathrm{DERM}_{\mathrm{m}}$ (see Table 1). The influence of incubation time (either antagonistic or synergistic) on litter mixing is consistent with previous studies (Wardle et al. 1997). The change in $\mathrm{DERM}_{\mathrm{m}}$ over time could be accounted for by the temporal variations of microclimate, decomposer community and litter chemistry in the decomposition processes. The early phase of decomposition is mainly driven by nutrients, whereas secondary compounds (e.g. lignin) influence the later decomposition stage (Berg and McClaugherty 2014).

One of the mechanisms behind positive litter mixture effects is the active microbial nutrient transfer from nutrient-rich to nutrient-poor litter (Gessner et al. 2010), which is expected to increase with chemical dissimilarity. For instance, it has been shown that fungi growing in nutrient-poor litter can redistribute limiting nutrients, such as $\mathrm{P}$, by extending their hyphae to the richer litter species (Schimel and Hättenschwiler 2007). In the present case, however, the effect of chemical dissimilarity was only significant through an interaction with time (main chemical dissimilarity effect not significant), which suggests that other mechanisms are at play. In addition to this active translocation, passive transfers via leaching and subsequent transport by water flow of soluble nutrients and carbon compounds can occur. Some recalcitrant and/or inhibitory compounds (e.g. lignin and/or tannins) can also be involved in such passive transfers leading to negative effects on decomposition as observed after 6 months of incubation in this study (Gartner and Cardon 2004; Hättenschwiler et al. 2005).

The mixture identity effect explained a large part of the variability in $\mathrm{DERM}_{\mathrm{m}}$. For both incubation durations, the overall net outcomes were driven by a limited number of mixtures, the great majority showing neither significantly positive nor negative $\mathrm{DERM}_{\mathrm{m}}$. After 6 months, only six pairwise species exhibited strong negative $D_{E R M_{m}}$ ranging from 4.28 to $-7.27 \%$, while all the other mixtures ranged from 3.03 to $+3.37 \%$. As shown by numerous studies, when nonadditive mixing effects occur, differences between observed and predicted mass loss up to $20 \%$ are common (Gartner and Cardon 2004; Hättenschwiler et al. 2005).

Looking at the individual components of the mixture through $\mathrm{DERM}_{\mathrm{t}}$ allowed to further interpret the results at the whole mixture level. In particular, the lack of any interaction at the whole mixture level could be associated with contrasting responses of the components. As an example, mixedspecies litterbags including $C$. hankei and G. thompsonii exhibited an additive effect after 6 months $\left(\mathrm{DERM}_{\mathrm{m}}=0.30\right.$, $P>0.05)$, whereas species-specific responses were contrasted with DERM $\mathrm{t}_{\mathrm{t}}$ of $+5.79 \%\left(P<10^{-3}\right)$ for $C$. hankei in the presence of $G$. thompsonii and of $-5.40 \%$ for $G$. thompsonii in the presence of $C$. hankei. Conversely, for mixed-species litterbag including $J$. seretii litter, the null $\mathrm{DERM}_{\mathrm{m}}$ reflects a true 
additive effect. Indeed, after 6 months of incubation, the individual decomposition of $J$. seretii was not affected by mixing and the presence of $J$. seretii had on average no impact on the litter mass loss of its neighbours.

As shown in Table 2, DERM $\mathrm{t}_{\mathrm{t}}$ was mostly influenced by incubation time, mixture identity and their interaction. Despite the marked differences in litter chemistry among the eight involved species, ranging from fast-decomposing $(S$. zenkeri and $G$. thompsonii) to recalcitrant ( $G$. dewevrei and C. hankei), the main chemical dissimilarity effect only explained a minor $(2.7 \%)$ part of $\mathrm{DERM}_{\mathrm{t}}$. In addition, chemical dissimilarity also interacted significantly with both time and litter quality of the target species, which precludes any generalisation about its effect. So, while the mixture identity effect on DERM $\mathrm{H}_{t}$ suggests a major impact of neighbour identity on the decomposition of the target species, the latter cannot be consistently related to chemical dissimilarity.

This result is surprising, given that functional diversity is known to be a major driver of litter mixture effects (Finerty et al. 2016; García-Palacios et al. 2017). However, some studies also reported no significant effect of plant trait dissimilarity on litter mixture decomposition (Barantal et al. 2011; Frainer et al. 2015; Lin and Zeng 2018), which suggests that the effect of functional diversity in explaining mixture effect is much lower compared to that of functional identity.

However, over 6 months, we may have missed some shifts in the magnitude and in the direction of litter mixture effects on decay rates in response to change in local environment conditions, in decomposer community or in litter quality as decay proceeds. Also, we only used two-way combinations to investigate mixture effects which limits a thorough assessment of diversity effects. Nevertheless, our approach allowed us to more easily separate the component species within the mixed litterbags and to highlight species-specific responses.

\subsection{Home-field advantage}

Initial mass losses (during the first 2 months) of the dominant species ( $S$. zenkeri and $G$. dewevrei in mixed and monodominant forests, respectively) were significantly different between both forest types (Table 3, Fig. 6). The litters of $S$. zenkeri and $G$. dewevrei showed a smaller remaining mass (from -8.63 to $-17.85 \%$ ) in their environment of origin, suggesting an HFA. The magnitude of this HFA was higher than the average value of 5.6\% reported by Veen et al. (2015) in their literature review; however, HFA is often associated to a large variability, indicating considerable variation in the magnitude and direction between observations.

Considering the first 2 months of incubation, our results are also in agreement with the SMI hypothesis. While the chemical dissimilarity hypothesis pertains to mixtures of leaf litters and assumes synergistic effects to increase with chemical dissimilarity between the individual components, the SMI hypothesis pertains to the impact of the decomposition environment on the decay of specific litters; it expects a continuum from positive to negative interaction between specific litters and decomposer communities as specific litters and the ecosystem litter matrix become increasingly dissimilar in quality (Freschet et al. 2012b). In our case, the $S$. zenkeri and $G$. dewevrei leaf litters are among the most contrasted substrates in terms of quality (Fig. 2b) and decay rates (Fig. 2), and the corresponding mixed and monodominant forests are associated with similarly contrasted average litter matrix qualities (Cassart et al. 2017). Altogether, the results from the first decomposition stages strongly suggest that each litter type has its own specialised decomposer community, irrespective of litter quality; also, they do not support the hypothesis in which low litter quality environments would have a high functional capacity to degrade all litter types (van der Heijden et al. 2008), as otherwise we might have expected no or only limited HFA effect for $S$. zenkeri leaf litter.

The contrasting patterns observed between the two species as decomposition proceeds further, however, indicate that additional processes are at play (Austin et al. 2014). The disappearance of any effect related to the decomposition environment at 3 and 6 months for $G$. dewevrei could be due to the initial leaching of toxic components for the local 'foreign' decomposer community (Berg and McClaugherty 2014), to a change in the input litter chemistry due to the activity of the local microbial community (Wickings et al. 2011), or to a shift in the structure and composition of the local decomposers (Gießelmann et al. 2011); in any case, it appears that the decomposers associated with the litter matrix under mixed forests can cope with a large range of litter types, even with some delay, which is in agreement with such multispecies ecosystems (Cassart et al. 2017). Contrary to the recalcitrant $G$. dewevrei leaf litter, the $S$. zenkeri substrate continues to show a strong home-field advantage at 6 months, while its decay rate is nevertheless strongly reduced (Fig. 2b); this suggests a strong specialisation of the decomposers community under monodominant forests.

Results from other studies indicate that home-field effects can strongly depend on environmental context. For instance, Torti et al. (2001) reported substantially lower litter mass loss for $G$. dewevrei under its own environment of origin compared to the adjacent mixed forest in the Ituri Forest (250 km east of Kisangani) and attributed this negative effect to higher mesofauna activity under the mixed forest. In Cameroon, Peh et al. (2012) observed no significant forest type effect on litter decomposition of different species including G. dewevrei.

In this experiment, the short duration of the incubation or the exclusion of macrofauna may have led to an underestimation of the HFA. Indeed, animals adapted to specific litter type may selectively bury some litter fragments as a food store or to line nests or tunnels (Jouquet et al. 2011). 


\section{Conclusions}

Our results showed that when site conditions are kept similar, leaf litter quality is the major driver of litter decomposition under Central African tropical rainforests. We also showed that combining all studied litter traits into a multivariate measure of leaf litter quality resulted in an improved prediction of decay rates compared to the use of single traits as predictors. Because this litter quality indicator was also closely related to a multivariate measure of green leaves quality, it could be considered as a proxy of LES. The contrasted position of the two dominant species (S. zenkeri and $G$. dewevrei for mixed and monodominant forests, respectively) along this proxy of LES was associated with strongly different decay rates, in close agreement with the greatest organic matter accumulation in mineral soil and forest floor under monodominant forests (Cassart et al. 2017).

Compared to average leaf litter quality, the direct litter mixing effects were weak yet significant. At both the whole mixture and species-component levels, those effects were mainly explained by incubation time, mixture identity and their interaction. Contrary to expectations, chemical dissimilarity only explained a minor part of the significant interactive effects observed in litter mixtures. In addition to these direct litter mixture diversity effects, the decomposition of S. zenkeri and $G$. dewevrei was affected by their environment, both species exhibiting more favourable initial decay rates under their own forest types in agreement with the HFA.

While still incomplete, our results help to expand the understanding of the decomposition process and more particularly the implication of local environment and community functional traits. Given that land use change is happening on a large scale and leads to radical changes in species composition, our study shows that we may expect great impacts on nutrient and carbon cycling. Furthermore, a better understanding of such complex process is invaluable to support models of climate and land-use change on ecosystems and to inform policies related to climate change mitigation.

Acknowledgements All the authors thank the numerous persons who contributed to the field work in DRC. They are also grateful to Karine Henin who carried out most of the chemical analyses. Three anonymous referees helped greatly in improving the clarity of this manuscript.

Contributions of the co-authors $\mathrm{BC}$ and $\mathrm{QP}$ conceived and designed the experiments. $\mathrm{ABA}$ and $\mathrm{BC}$ performed the experiments. $\mathrm{BC}, \mathrm{MJ}$ and $\mathrm{QP}$ analysed the data.

Data availability statement Access will be provided upon reasonable request.

Funding information Benoit Cassart obtained a $\mathrm{PhD}$ grant from the 'Fonds National de la Recherche Scientifique' (FNRS-FRIA) and received additional support for field work and laboratory analyses from a joint WBI-ERAIFT grant. Albert Angbonga Basia was funded by the 'AFORCO - Appui à l'organisation d'un master en aménagement forestier pour le renforcement des capacités des chercheurs congolais en vue de la relance socio-économique de la République Démocratique du Congo' project, funded by the 'Commission Universitaire au Développement' (CUD, ARES-CCD) and coordinated by Prof. Jan Bogaert (ULg - Gembloux Agro-Bio Tech).

\section{Compliance with ethical standards}

Conflict of interest The authors declare that they have no conflicts of interest.

\section{Appendix}

Table 4 Chemical composition of the leaf litter of the eight tree species used in the decomposition experiment

\begin{tabular}{|c|c|c|c|c|c|c|c|c|c|c|c|c|c|c|}
\hline \multirow[t]{2}{*}{ Species } & \multicolumn{8}{|c|}{ Nutrients $\left(\mathrm{mg} \mathrm{g}^{-1}\right)$} & \multirow{2}{*}{$\begin{array}{l}\text { Lignin } \\
\left(\mathrm{mg} \mathrm{g}^{-1}\right)\end{array}$} & \multirow[t]{2}{*}{ Cellulose } & \multicolumn{4}{|c|}{ Selected ratios } \\
\hline & $\overline{\mathrm{N}}$ & $\mathrm{Ca}$ & $\bar{K}$ & $\mathrm{P}$ & $\mathrm{Mn}$ & $\mathrm{Mg}$ & $\mathrm{S}$ & $\overline{\mathrm{Si}}$ & & & $\overline{\mathrm{C}: \mathrm{N}}$ & $\mathrm{C}: \mathrm{S}$ & $\mathrm{N}: \mathrm{P}$ & $\overline{\text { Lignin:N }}$ \\
\hline A. mannii & 27.5 & 7.7 & 5.0 & 1.4 & 1.9 & 3.4 & 5.8 & 6.0 & 287.2 & 435.9 & 18.0 & 85.3 & 19.3 & 10.5 \\
\hline C. hankei & 25.9 & 8.3 & 6.6 & 1.2 & 1.2 & 1.3 & 1.7 & 9.5 & 507.9 & 344.9 & 20.1 & 302.0 & 21.5 & 19.7 \\
\hline G. dewevrei & 14.5 & 5.4 & 4.0 & 0.6 & 0.03 & 2.2 & 1.3 & 24.4 & 391.7 & 338.0 & 33.8 & 385.2 & 25.9 & 27.0 \\
\hline G. thompsonii & 29.2 & 13.6 & 24.1 & 2.5 & 0.1 & 3.2 & 4.9 & 7.2 & 261.8 & 302.4 & 16.7 & 99.7 & 11.9 & 9.0 \\
\hline J. seretii & 15.0 & 8.2 & 4.1 & 0.6 & 2.7 & 1.7 & 2.7 & 20.2 & 399.0 & 352.1 & 33.6 & 186.8 & 24.6 & 26.6 \\
\hline P. suaveolens & 31.2 & 10.7 & 7.9 & 1.3 & 3.1 & 3.1 & 5.4 & 7.3 & 348.4 & 335.4 & 16.3 & 93.7 & 23.6 & 11.2 \\
\hline P. oxyphylla & 16.3 & 11.5 & 2.6 & 0.6 & 3.6 & 2.2 & 2.0 & 11.2 & 402.1 & 385.1 & 30.6 & 251.1 & 27.4 & 24.7 \\
\hline S. zenkeri & 30.7 & 14.0 & 7.7 & 1.5 & 3.5 & 3.2 & 9.7 & 17.5 & 302.7 & 328.4 & 15.5 & 48.8 & 20.3 & 9.9 \\
\hline
\end{tabular}


Table 5 Mixed-species litterbags' identity

\begin{tabular}{ll}
\hline ID & Mixture \\
\hline 1 & A. mannii + P. suaveolens \\
2 & C. hankei + A. mannii \\
3 & C. hankei + G. thompsonii \\
4 & C. hankei + J. seretii \\
5 & C. hankei + P. suaveolens \\
6 & C. hankei + P. oxyphylla \\
7 & G. dewevrei + A. mannii \\
8 & G. dewevrei + C. hankei \\
9 & G. dewevrei + G. thompsonii \\
10 & G. dewevrei + J. seretii \\
11 & G. dewevrei + P. suaveolens \\
12 & G. dewevrei + P. oxyphylla \\
13 & G. thompsonii + A. mannii \\
14 & G. thompsonii + P. suaveolens \\
15 & J. seretii + A. mannii \\
16 & J. seretii + G. thompsonii \\
17 & J. seretii + P. suaveolens \\
18 & J. seretii + P. oxyphylla \\
19 & P. oxyphylla + A. mannii \\
20 & P. oxyphylla + G. thompsonii \\
21 & P. oxyphylla + P. suaveolens \\
22 & S. zenkeri + A. mannii \\
23 & S. zenkeri + C. hankei \\
24 & S. zenkeri + G. dewevrei \\
25 & S. zenkeri + G. thompsonii \\
26 & S. zenkeri + J. seretii \\
27 & S. zenkeri + P. suaveolens \\
28 & S. zenkeri + P. oxyphylla \\
& \\
\hline &
\end{tabular}

Fig. 7 Relative litter mass remaining (RM) after 1, 2, 3 and 6 months for the single-species litterbags of A. mannii, C. hankei, G. dewevrei, G. thompsonii, $J$. seretii, P. suaveolens, $P$. oxyphylla and $S$. zenkeri under mixed forests in the Yoko Reserve. The summary and the parameter estimates of the decay rate model $\mathrm{RM}=\exp \left(-(t / b)^{\mathrm{a}}\right)$ are given in the captions
A. mannii

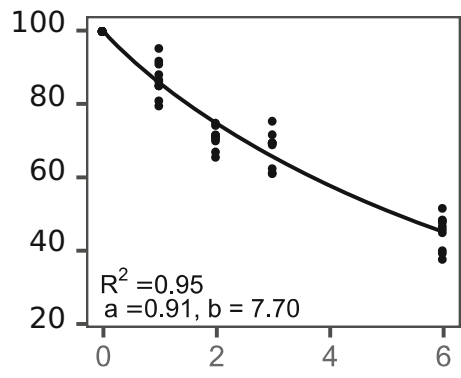

G. thompsonii

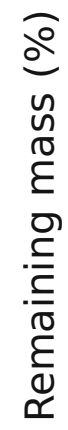

C. hankei

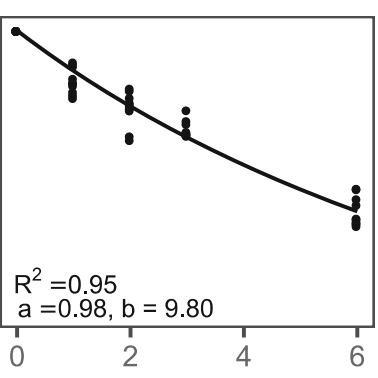

J. seretii

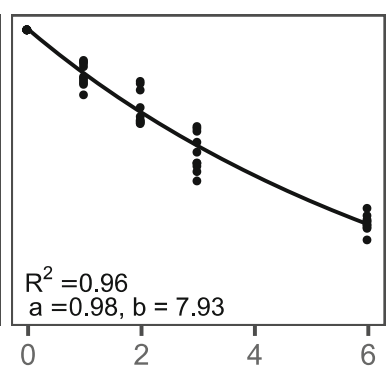

S. zenkeri

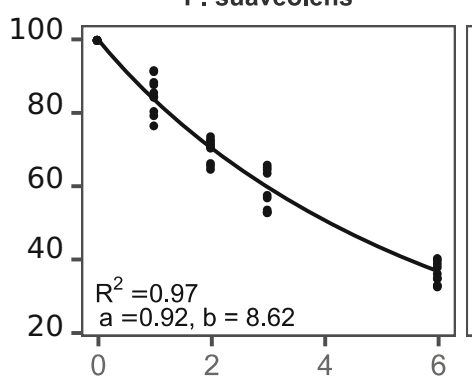

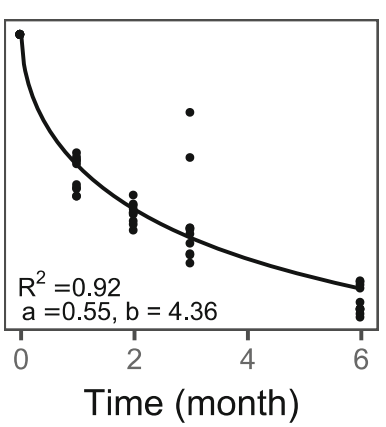

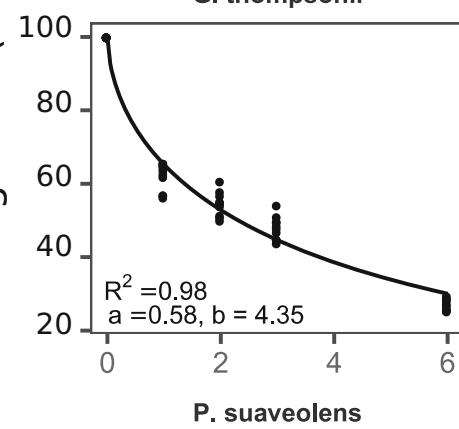

G. dewevrei

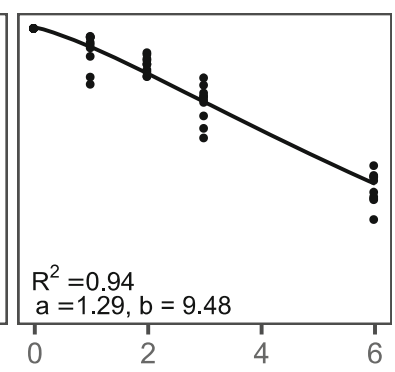

P. oxyphylla

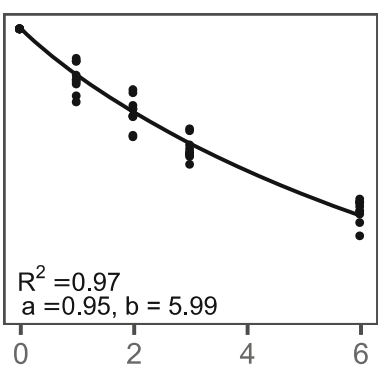

$$
\text { ( }
$$



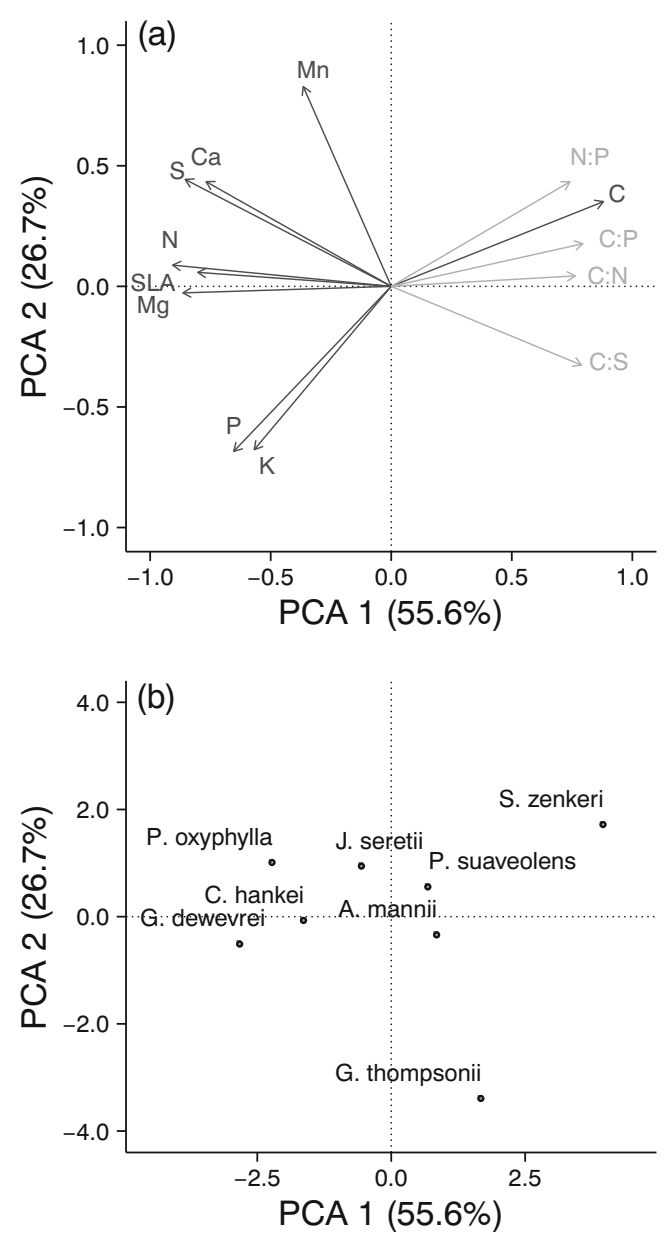

Fig. 8 Principal component analysis of nine green leaf traits of eight tropical tree species (black points). Projection of a variables and $\mathbf{b}$ species on the first two axes. Eigenvalue of axis 1 and axis 2 is 4.44 and 2.13, respectively, explaining 55.6 and $26.7 \%$ of the variation, respectively. Active variables included in the analysis (black arrows): $\mathrm{C}$, $\mathrm{Ca}, \mathrm{K}, \mathrm{Mg}, \mathrm{Mn}, \mathrm{N}, \mathrm{P}$ and $\mathrm{S}$ green leaf concentrations and specific leaf area (SLA). Chemical traits included as illustrative variables (grey arrows): $\mathrm{C}: \mathrm{N}, \mathrm{C}: \mathrm{S}, \mathrm{C}: \mathrm{P}$ and $\mathrm{N}: \mathrm{P}$ green leaf ratios 

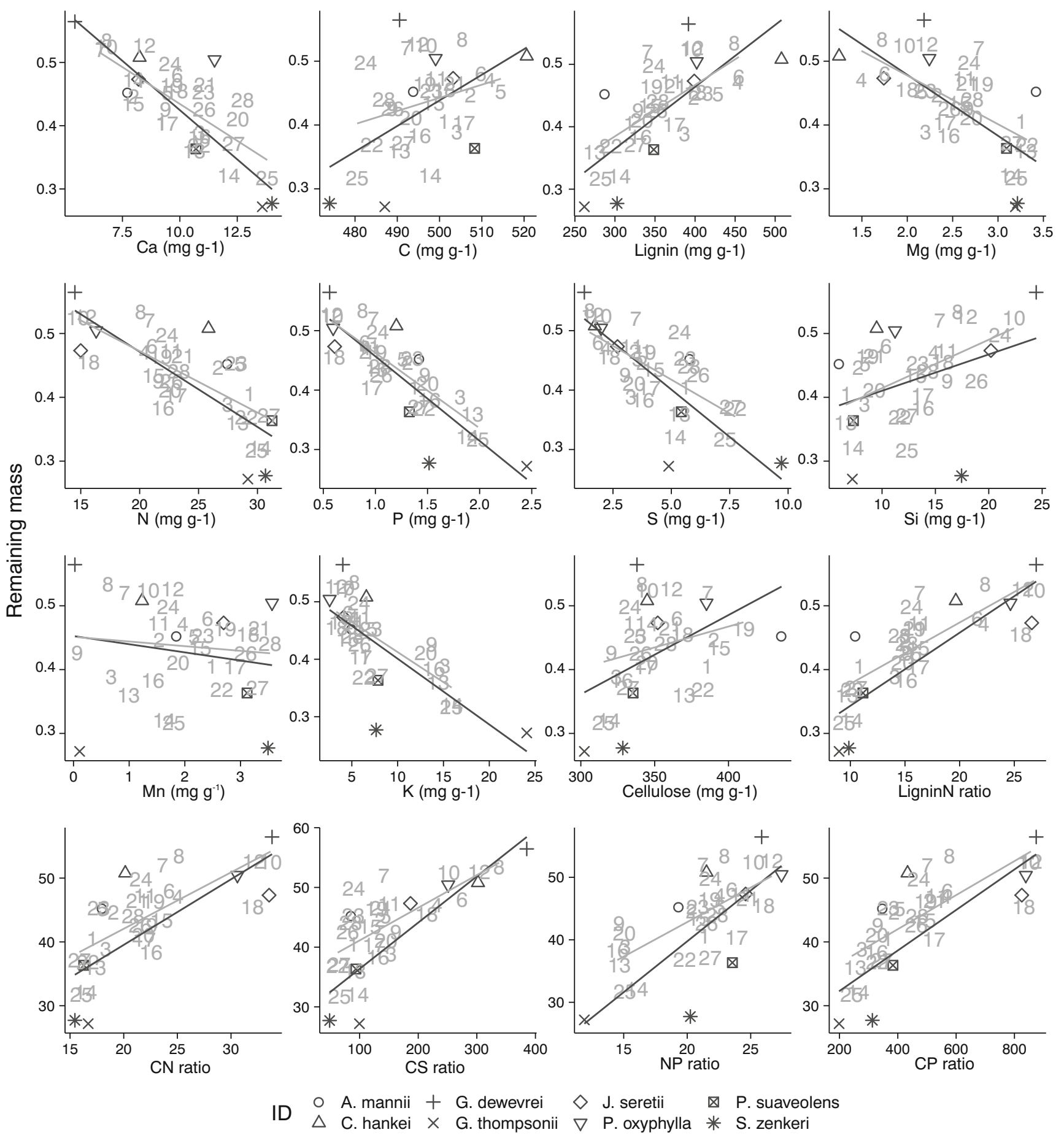

Fig. 9 Remaining mass (\%) after 6 months of incubation under mixed forests for eight tropical tree species and all their two-way combinations Appendix) as a function of $\mathrm{C}, \mathrm{Ca}$, cellulose, $\mathrm{K}$, lignin, $\mathrm{Mg}, \mathrm{Mn}, \mathrm{N}$ and $\mathrm{P}$ leaf litter concentrations and C:P, C:N, C:S, N:P and lignin:N leaf litter ratios in the Yoko Reserve 


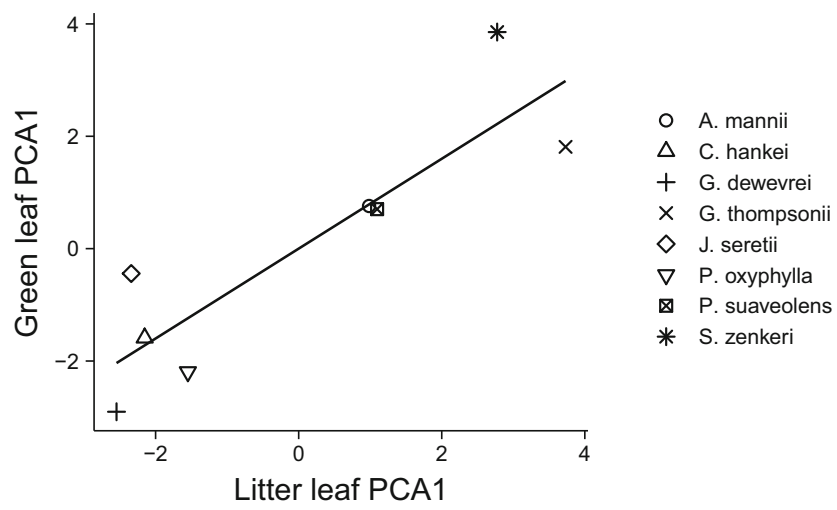

Fig. 10 Position of the eight tree species along the first axis of the green leaf traits PCA as a function of their position along the first axis of the leaf litter traits PCA. $R^{2}$ of the fitted line $0.75\left(P<10^{-3}\right)$

\section{References}

Aerts R (1997) Climate, leaf litter chemistry and leaf litter decomposition in terrestrial ecosystems: a triangular relationship. Oikos 79:439. https://doi.org/10.2307/3546886

Austin AT, Vivanco L, González-Arzac A, Pérez LI (2014) There's no place like home? An exploration of the mechanisms behind plant litter-decomposer affinity in terrestrial ecosystems. New Phytol 204

Ayres E, Steltzer H, Simmons BL et al (2009) Home-field advantage accelerates leaf litter decomposition in forests. Soil Biol Biochem 41:606-610. https://doi.org/10.1016/j.soilbio.2008.12.022

Bakker MA, Carreño-Rocabado G, Poorter L (2011) Leaf economics traits predict litter decomposition of tropical plants and differ among land use types. Funct Ecol 25:473-483. https://doi.org/10.1111/j. 1365-2435.2010.01802.x

Baraloto C, Paine CET, Poorter L et al (2010) Decoupled leaf and stem economics in rain forest trees. Ecol Lett 13:1338-1347

Barantal S, Roy J, Fromin N, Schimann H, Hättenschwiler S (2011) Longterm presence of tree species but not chemical diversity affect litter mixture effects on decomposition in a Neotropical rainforest. Oecologia 167:241-252. https://doi.org/10.1007/s00442-011-1966-4

Berg B (2014) Decomposition patterns for foliar litter - a theory for influencing factors. Soil Biol Biochem 78:222-232

Berg B, McClaugherty CA (2014) Plant litter. Decomposition, humus formation, carbon sequestration. Springer, Berlin

Berg B, Steffen KT, McClaugherty C (2007) Litter decomposition rate is dependent on litter Mn concentrations. Biogeochemistry 82:29-39. https://doi.org/10.1007/s10533-006-9050-6

Bernhard-Reversat F, Schwartz D (1997) Change in lignin content during litter decomposition in tropical forest soils (Congo): comparison of exotic plantations and native stands. Comptes Rendus de l'Académie des Sciences - Series IIA - Earth Planet Sci 325:427-432

Cassart B, Angbonga Basia A, Titeux H et al (2017) Contrasting patterns of carbon sequestration between Gilbertiodendron dewevrei monodominant forests and Scorodophloeus zenkeri mixed forests in the Central Congo basin. Plant Soil 414:309-326. https://doi. org/10.1007/s11104-016-3130-8

Cebrian J (1999) Patterns in the fate of production in plant communities. Am Nat 154:449-468. https://doi.org/10.1086/303244

Chapin FS, Matson PA, Vitousek PM (2011) Decomposition and ecosystem carbon budgets. In: Principles of terrestrial ecosystem ecology. Springer, New York, pp 183-228

Chuyong GB, Newbery DM, Songwe NC (2002) Litter breakdown and mineralization in a Central African rain forest dominated by ectomycorrhizal Trees. Biogeochemistry 61:73-94. https://doi.org/ 10.1023/A:1020276430119

Cleveland CC, Townsend AR, Schmidt SK (2002) Phosphorus limitation of microbial processes in moist tropical forests: evidence from shortterm laboratory incubations and field studies. Ecosystems 5:0680 0691. https://doi.org/10.1007/s10021-002-0202-9

Connell JH, Lowman MD (1989) Low-diversity tropical rain forests: some possible mechanisms for their existence. Am Nat 134:88 119. https://doi.org/10.1086/284967

Cornelissen JHC, Lavorel S, Garnier E et al (2003) A handbook of protocols for standardised and easy measurement of plant functional traits worldwide. Aust J Bot 51:335-380

Cornwell WK, Weedon JT (2014) Decomposition trajectories of diverse litter types: a model selection analysis. Methods Ecol Evol 5:173182. https://doi.org/10.1111/2041-210X.12138

Coûteaux M-M, Bottner P, Berg B (1995) Litter decomposition, climate and liter quality. Trends Ecol Evol 10:63-66. https://doi.org/10. 1016/S0169-5347(00)88978-8

Djomo AN, Knohl A, Gravenhorst G (2011) Estimations of total ecosystem carbon pools distribution and carbon biomass current annual increment of a moist tropical forest. For Ecol Manag 261:14481459. https://doi.org/10.1016/j.foreco.2011.01.031

Fanin N, Hättenschwiler S, Fromin N (2014) Litter fingerprint on microbial biomass, activity, and community structure in the underlying soil. Plant Soil 379:79-91. https://doi.org/10.1007/s11104-0142051-7

Feng Y, Li X (2001) An analytical model of soil organic carbon dynamics based on a simple "hockey stick" function. Soil Sci 166:431-440. https://doi.org/10.1097/00010694-200107000-00001

Finerty GE, de Bello F, Bílá K et al (2016) Exotic or not, leaf trait dissimilarity modulates the effect of dominant species on mixed litter decomposition. J Ecol 104:1400-1409. https://doi.org/10. $1111 / 1365-2745.12602$

Four B, Cárdenas RE, Dangles O (2019) Traits or habitat? Disentangling predictors of leaf-litter decomposition in Amazonian soils and streams. Ecosphere 10:e02691. https://doi.org/10.1002/ecs2.2691

Frainer A, Moretti MS, Xu W, Gessner MO (2015) No evidence for leaftrait dissimilarity effects on litter decomposition, fungal decomposers, and nutrient dynamics. Ecology 96:550-561

Freschet GT, Aerts R, Cornelissen JHC (2012a) Multiple mechanisms for trait effects on litter decomposition: moving beyond home-field advantage with a new hypothesis. J Ecol 100:619-630. https://doi.org/ 10.1111/j.1365-2745.2011.01943.x

Freschet GT, Weedon JT, Aerts R et al (2012b) Interspecific differences in wood decay rates: insights from a new short-term method to study long-term wood decomposition. J Ecol 100:161-170. https://doi. $\operatorname{org} / 10.1111 / j .1365-2745.2011 .01896 . x$

García-Palacios P, Shaw EA, Wall DH, Hättenschwiler S (2017) Contrasting mass-ratio vs. niche complementarity effects on litter $\mathrm{C}$ and $\mathrm{N}$ loss during decomposition along a regional climatic gradient. J Ecol 105:968-978. https://doi.org/10.1111/1365-2745.12730

Gartner TB, Cardon ZG (2004) Decomposition dynamics in mixedspecies leaf litter. Oikos 104:230-246. https://doi.org/10.1111/j. 0030-1299.2004.12738.x

Gessner MO, Swan CM, Dang CK et al (2010) Diversity meets decomposition. Trends Ecol Evol 25:372-380. https://doi.org/10.1016/j. tree.2010.01.010

Gießelmann UC, Martins KG, Brändle M et al (2011) Lack of home-field advantage in the decomposition of leaf litter in the Atlantic rainforest of Brazil. Appl Soil Ecol 49:5-10. https://doi.org/10.1016/j.apsoil. 2011.07.010

Grime JP (1998) Benefits of plant diversity to ecosystems: immediate, filter and founder effects. J Ecol 86:902-910

Hart TB, Hart JA, Murphy PG (1989) Monodominant and species-rich forests of the humid tropics: causes for their co-occurrence. Am Nat 133:613-633 
Hättenschwiler S, Tiunov AV, Scheu S (2005) Biodiversity and litter decomposition in terrestrial ecosystems. Annu Rev Ecol Evol Syst 36:191-218. https://doi.org/10.1146/annurev.ecolsys.36.112904. 151932

Hättenschwiler S, Coq S, Barantal S, Handa IT (2011) Leaf traits and decomposition in tropical rainforests: revisiting some commonly held views and towards a new hypothesis. New Phytol 189:950-965

Hoorens B, Aerts R, Stroetenga M (2003) Does initial litter chemistry explain litter mixture effects on decomposition? Oecologia 137: 578-586. https://doi.org/10.1007/s00442-003-1365-6

Hoorens B, Coomes D, Aerts R (2010) Neighbour identity hardly affects litter-mixture effects on decomposition rates of New Zealand forest species. Oecologia 162:479-489

Jewell MD, Shipley B, Paquette A, Messier C, Reich PB (2015) A traitsbased test of the home-field advantage in mixed-species tree litter decomposition. Ann Bot 116:781-788. https://doi.org/10.1093/aob/ mev105

Joanisse GD, Bradley RL, Preston CM, Munson AD (2007) Soil enzyme inhibition by condensed litter tannins may drive ecosystem structure and processes: the case of Kalmia angustifolia. New Phytol 175: 535-546. https://doi.org/10.1111/j.1469-8137.2007.02113.x

Joly F-X, Milcu A, Scherer-Lorenzen M, Jean LK, Bussotti F, Dawud SM, Müller S, Pollastrini M, Raulund-Rasmussen K, Vesterdal L, Hättenschwiler S (2017) Tree species diversity affects decomposition through modified micro-environmental conditions across European forests. New Phytol 214:1281-1293. https://doi.org/10. 1111/nph.14452

Jouquet P, Traoré S, Choosai C et al (2011) Influence of termites on ecosystem functioning. Ecosystem services provided by termites. Eur J Soil Biol 47:215-222. https://doi.org/10.1016/j.ejsobi.2011. 05.005

Kearsley E, Verbeeck H, Hufkens K, van de Perre F, Doetterl S, Baert G, Beeckman H, Boeckx P, Huygens D (2017) Functional community structure of African monodominant Gilbertiodendron dewevrei forest influenced by local environmental filtering. Ecol Evol 7:295304. https://doi.org/10.1002/ece3.2589

Keiluweit M, Nico P, Harmon ME et al (2015) Long-term litter decomposition controlled by manganese redox cycling. Proc Natl Acad Sci 112:E5253-E5260. https://doi.org/10.1073/pnas.1508945112

Kraus TEC, Dahlgren RA, Zasoski RJ (2003) Tannins in nutrient dynamics of forest ecosystems - a review. Plant Soil 256:41-66

Lecerf A, Marie G, Kominoski JS, LeRoy C, Bernadet C, Swan CM (2011) Incubation time, functional litter diversity, and habitat characteristics predict litter-mixing effects on decomposition. Ecology 92:160-169. https://doi.org/10.1890/10-0315.1

Lin G, Zeng D-H (2018) Functional identity rather than functional diversity or species richness controls litter mixture decomposition in a subtropical forest. Plant Soil 428:179-193. https://doi.org/10.1007/ s11104-018-3669-7

Lovett GM, Arthur MA, Crowley KF (2016) Effects of calcium on the rate and extent of litter decomposition in a northern hardwood forest. Ecosystems 19:87-97. https://doi.org/10.1007/s10021-015-9919-0

Manzoni S, Pineiro G, Jackson RB et al (2012) Analytical models of soil and litter decomposition: solutions for mass loss and time-dependent decay rates. Soil Biol Biochem 50:66-76

McClaugherty C, Berg B (1987) Cellulose, lignin and nitrogen concentrations as rate regulating factors in late stages of forest litter decomposition. Pedobiologia (Jena) 30:101-112

Nottingham AT, Hicks LC, Ccahuana AJQ, Salinas N, Bååth E, Meir P (2018) Nutrient limitations to bacterial and fungal growth during cellulose decomposition in tropical forest soils. Biol Fertil Soils 54:219-228. https://doi.org/10.1007/s00374-017-1247-4

Oliveira RAC, Marques R, Marques MCM (2019) Plant diversity and local environmental conditions indirectly affect litter decomposition in a tropical forest. Appl Soil Ecol 134:45-53. https://doi.org/10. 1016/j.apsoil.2018.09.016
Olson JS (1963) Energy storage and the balance of producers and decomposers in ecological systems. Ecology 44:322-331. https://doi.org/ $10.2307 / 1932179$

Osnas JLD, Lichstein JW, Reich PB, Pacala SW (2013) Global leaf trait relationships: mass, area, and the leaf economics spectrum. Science (80- ) 340:741-744

Peel MC, Finlayson BL, McMahon TA (2007) Updated world map of the Köppen-Geiger climate classification. Hydrol Earth Syst Sci 11: 1633-1644. https://doi.org/10.5194/hess-11-1633-2007

Peh KS-H (2009) The relationship between species diversity and ecosystem function in low- and high-diversity Tropical African forests. The University of Leeds

Peh KSH, Lewis SL, Lloyd J (2011) Mechanisms of monodominance in diverse tropical tree-dominated systems. J Ecol 99:891-898

Peh KSH, Sonké B, Taedoung H et al (2012) Investigating diversity dependence of tropical forest litter decomposition: experiments and observations from Central Africa. J Veg Sci 23:223-235

Poorter L, Bongers F (2006) Leaf traits are good predictors of plant performance across 53 rain forest species. Ecology 87:1733-1743. https://doi.org/10.1890/0012-9658(2006)87[1733:LTAGPO]2.0. $\mathrm{CO} ; 2$

Powers JS, Montgomery RA, Adair EC et al (2009) Decomposition in tropical forests: a pan-tropical study of the effects of litter type, litter placement and mesofaunal exclusion across a precipitation gradient. J Ecol 97:801-811. https://doi.org/10.1111/j.1365-2745.2009. 01515.x

Reich PB, Walters MB, Ellsworth DS (1997) From tropics to tundra: global convergence in plant functioning. Proc Natl Acad Sci 94: 13730-13734

Reynolds OL, Keeping MG, Meyer JH (2009) Silicon-augmented resistance of plants to herbivorous insects: a review. Ann Appl Biol 155: 171-186. https://doi.org/10.1111/j.1744-7348.2009.00348.x

Santiago LS (2007) Extending the leaf economics spectrum to decomposition: evidence from a tropical forest. Ecology 88:1126-1131. https://doi.org/10.1890/06-1841

Scalbert A (1991) Antimicrobial properties of tannins. Phytochemistry 30:3875-3883

Scherer-Lorenzen M (2008) Functional diversity affects decomposition processes in experimental grasslands. Funct Ecol 22:547-555. https://doi.org/10.1111/j.1365-2435.2008.01389.x

Schimel JP, Hättenschwiler S (2007) Nitrogen transfer between decomposing leaves of different N status. Soil Biol Biochem 39: 1428-1436. https://doi.org/10.1016/j.soilbio.2006.12.037

Schimel JP, Van Cleve K, Cates RG et al (1996) Effects of balsam poplar (Populus balsamifera) tannins and low molecular weight phenolics on microbial activity in taiga floodplain soil: implications for changes in $\mathrm{N}$ cycling during succession. Can J Bot 74:84-90. https://doi. org $/ 10.1139 / \mathrm{b} 96-012$

Shipley B, Lechowicz MJ, Wright I, Reich PB (2006) Fundamental tradeoffs generating the worldwide leaf economics spectrum. Ecology 87:535-541. https://doi.org/10.1890/05-1051

Swift MJ, Heal OW, Anderson JM (1979) Decomposition in terrestrial ecosystems. University of California Press, Berkeley

Torti SD, Coley PD, Kursar TA (2001) Causes and consequences of monodominance in tropical lowland forests. Am Nat 157:141153. https://doi.org/10.1086/318629

van der Heijden MGA, Bardgett RD, van Straalen NM (2008) The unseen majority: soil microbes as drivers of plant diversity and productivity in terrestrial ecosystems. Ecol Lett 11:296-310. https://doi.org/10. 1111/j.1461-0248.2007.01139.x

Van Ranst E, Baert G, Ngongo M, Mafuka P (2010) Carte pédologique de Yangambi, planchette 2: Yangambi, échelle 1:50.000. UGent; Hogent; UNILU; UNIKIN

Van Soest PJ, Wine RH (1967) Use of detergents in the analysis of fibrous feeds. IV Determination of plant cell-wall constituents. J AssocOff Anal Chem 50:50-55 
Veen GFC, Freschet GT, Ordonez A, Wardle DA (2015) Litter quality and environmental controls of home-field advantage effects on litter decomposition. Oikos 124:187-195. https://doi.org/10.1111/oik. 01374

Veen GFC, Keiser AD, van der Putten WH, Wardle DA (2018) Variation in home-field advantage and ability in leaf litter decomposition across successional gradients. Funct Ecol 32:1563-1574. https:// doi.org/10.1111/1365-2435.13107

Verbeeck H, Betehndoh E, Maes W et al (2014) Functional leaf trait diversity of 10 tree species in Congolese secondary tropical forest. J Trop For Sci 26:409-419

Vitousek PM (1984) Litterfall, nutrient cycling, and nutrient limitation in tropical forests. Ecology 65:285-298. https://doi.org/10.2307/ 1939481

Wallenstein MD, Haddix ML, Ayres E et al (2013) Litter chemistry changes more rapidly when decomposed at home but converges during decomposition-transformation. Soil Biol Biochem 57:311319. https://doi.org/10.1016/J.SOILBIO.2012.09.027

Wardle DA (2006) The influence of biotic interactions on soil biodiversity. Ecol Lett 9:870-886
Wardle DA, Bonner KI, Nicholson KS (1997) Biodiversity and plant litter: experimental evidence which does not support the view that enhanced species richness improves ecosystem function. Oikos 79: $247-258$

Waring B (2012) A meta-analysis of climatic and chemical controls on leaf litter decay rates in tropical forests. Ecosystems 15:999-1009

Wickings K, Stuart Grandy A, Reed S, Cleveland C (2011) Management intensity alters decomposition via biological pathways. Biogeochemistry 104:365-379. https://doi.org/10.1007/s10533010-9510-x

Wright IJ, Reich PB, Westoby M et al (2004) The worldwide leaf economics spectrum. Nat 428:821-827

Zhang D, Hui D, Luo Y, Zhou G (2008) Rates of litter decomposition in terrestrial ecosystems: global patterns and controlling factors. J Plant Ecol 1:85-93. https://doi.org/10.1093/jpe/rtn002

Publisher's note Springer Nature remains neutral with regard to jurisdictional claims in published maps and institutional affiliations. 